\title{
Quantifying the volatility of organic aerosol in the southeastern US
}

\author{
Provat K. Saha ${ }^{1}$, Andrey Khlystov ${ }^{2}$, Khairunnisa Yahya ${ }^{3}$, Yang Zhang ${ }^{3}$, Lu Xu ${ }^{4}$, Nga L. Ng $^{4,5}$, and \\ Andrew P. Grieshop ${ }^{1}$ \\ ${ }^{1}$ Department of Civil, Construction and Environmental Engineering, North Carolina State University, Raleigh, NC, USA \\ ${ }^{2}$ Division of Atmospheric Sciences, Desert Research Institute, Reno, Nevada, USA \\ ${ }^{3}$ Department of Marine Earth and Atmospheric Sciences, North Carolina State University, Raleigh, NC, USA \\ ${ }^{4}$ School of Chemical and Biomolecular Engineering, Georgia Institute of Technology, Atlanta, GA, USA \\ ${ }^{5}$ School of Earth and Atmospheric Sciences, Georgia Institute of Technology, Atlanta, GA, USA
}

Correspondence to: Andrew P. Grieshop (apgriesh@ncsu.edu)

Received: 3 July 2016 - Published in Atmos. Chem. Phys. Discuss.: 9 August 2016

Revised: 17 November 2016 - Accepted: 7 December 2016 - Published: 11 January 2017

\begin{abstract}
The volatility of organic aerosols (OA) has emerged as a property of primary importance in understanding their atmospheric life cycle, and thus abundance and transport. However, quantitative estimates of the thermodynamic (volatility, water solubility) and kinetic parameters dictating ambient-OA gas-particle partitioning, such as saturation concentrations $\left(C^{*}\right)$, enthalpy of evaporation $\left(\Delta H_{\mathrm{vap}}\right)$, and evaporation coefficient $\left(\gamma_{\mathrm{e}}\right)$, are highly uncertain. Here, we present measurements of ambient-OA volatility at two sites in the southeastern US, one at a rural setting in Alabama dominated by biogenic volatile organic compounds (BVOCs) as part of the Southern Oxidant and Aerosol Study (SOAS) in June-July 2013, and another at a more anthropogenically influenced urban location in North Carolina during October-November 2013. These measurements applied a dual-thermodenuder (TD) system, in which temperature and residence times are varied in parallel to constrain equilibrium and kinetic aerosol volatility properties. Gas-particle partitioning parameters were determined via evaporation kinetic model fits to the dual-TD observations. OA volatility parameter values derived from both datasets were similar despite the fact that measurements were collected in distinct settings and seasons. The OA volatility distributions also did not vary dramatically over the campaign period or strongly correlate with OA components identified via positive matrix factorization of aerosol mass spectrometer data. A large portion (40$70 \%$ ) of measured ambient OA at both sites was composed of very-low-volatility organics $\left(C^{*} \leq 0.1 \mu \mathrm{g} \mathrm{m}^{-3}\right)$. An effective $\Delta H_{\text {vap }}$ of bulk OA of $\sim 80-100 \mathrm{~kJ} \mathrm{~mol}^{-1}$ and a $\gamma_{\mathrm{e}}$ value of $\sim 0.5$ best describe the evaporation observed in the TDs.
\end{abstract}

This range of $\Delta H_{\text {vap }}$ values is substantially higher than that typically assumed for simulating OA in atmospheric models $\left(30-40 \mathrm{~kJ} \mathrm{~mol}^{-1}\right)$. TD data indicate that $\gamma_{\mathrm{e}}$ is on the order of 0.1 to 0.5 , indicating that repartitioning timescales for atmospheric OA are on the order of several minutes to an hour under atmospheric conditions. The OA volatility distributions resulting from fits were compared to those simulated in the Weather, Research and Forecasting model with Chemistry (WRF/Chem) with a current treatment of secondary organic aerosol (SOA) formation. The substantial fraction of lowvolatility material observed in our measurements is largely missing from simulations, and OA mass concentrations are underestimated. The large discrepancies between simulations and observations indicate a need to treat low-volatility OA in atmospheric models. Volatility parameters extracted from ambient measurements enable evaluation of emerging treatments for OA (e.g., secondary OA using the volatility basis set or formed via aqueous chemistry) in atmospheric models.

\section{Introduction}

Organic aerosol (OA) is a dominant component of atmospheric fine particulate matter $\left(\mathrm{PM}_{2.5}\right)$ (Jimenez et al., 2009; Zhang et al., 2007), which is linked to adverse human health and uncertain climate effects. Atmospheric OA is a complex mixture of thousands of individual organic compounds originating from a range of natural and anthropogenic sources. Primary OA (POA) is emitted directly into the atmosphere. Secondary OA (SOA) is formed in the atmosphere via oxi- 
dation reactions of gas-phase organic species; it may also be formed by reactions in the particle (condensed) phase (Kroll and Seinfeld, 2008). A large fraction of SOA in many parts of the globe, e.g., in the southeastern US, is formed from biogenic volatile organic compounds (BVOCs) (Goldstein et al., 2009; Goldstein and Galbally, 2007). However, the mechanisms responsible for SOA production from BVOCs (Budisulistiorini et al., 2015; Goldstein and Galbally, 2007; Marais et al., 2016; Xu et al., 2015a, b), its chemical composition, and many important physical properties are largely undetermined (Goldstein et al., 2009; Schichtel et al., 2008; Weber et al., 2007). Therefore, their representation in current atmospheric and climate models are highly uncertain (Hallquist et al., 2009; Liao et al., 2007; Pye et al., 2015; Pye and Seinfeld, 2010).

One of the major sources of uncertainty in predicting SOA concentrations in atmospheric models arises from the poor understanding of gas-particle partitioning of chemical species comprising SOA (Hallquist et al., 2009; Jimenez et al., 2009; Seinfeld and Pankow, 2003). Gas-particle partitioning plays a central role in determining life cycle of OA and thus its atmospheric abundance, transport, and impacts (Donahue et al., 2006; Jimenez et al., 2009). At equilibrium, the volatility of organic species, specifically saturation vapor pressure (or equivalently, saturation concentration, $C^{*}$; $\mu \mathrm{g} \mathrm{m}^{-3}$ ), plays a vital role in determining their gas-particle partitioning. (Donahue et al., 2006; Pankow, 1994). Solubility of organic species in water may also be critical for gas-particle partitioning for many species (Hennigan et al., 2009), especially in places with higher relative humidity, in the southeastern US, for example. Enthalpies of vaporization $\left(\Delta H_{\text {vap }}\right)$ dictate the change in partitioning with temperature (Donahue et al., 2006; Epstein et al., 2010). Although gas-particle partitioning is determined by the basic thermodynamic properties of OA species - their $C^{*}, \Delta H_{\mathrm{vap}}$, and solubility - these, along with the impacts of nonideal mixing on individual species, are generally unknown for ambient $\mathrm{OA}$. Under changing conditions, gas-particle partitioning is also influenced by the kinetics of gas-particle exchange, for example due to barriers to mass transfer in solid or viscous particles or molecular accommodation at a particle surface (Kroll and Seinfeld, 2008). The overall kinetic limitation to mass transfer during repartitioning is typically described by an evaporation coefficient $\left(\gamma_{\mathrm{e}}\right)$ (also often called mass accommodation coefficient), which is highly uncertain for ambient OA and can dictate timescales for partitioning (Saleh et al., 2013). Though current models assume OA to be at equilibrium within a model prediction time step (several minutes to an hour) during atmospheric simulations, several studies have indicated that partitioning timescales could be as long as days or months $\left(\gamma_{\mathrm{e}} \ll 0.1\right)$ due to a highly viscous and/or glassy aerosol (Vaden et al., 2011; Zobrist et al., 2008).

Quantitative measures of ambient-OA gas-particle partitioning parameters are needed to provide inputs for, and to evaluate, atmospheric models. However, methods to quan- titatively determine ambient-OA volatility are in their infancy and the resulting estimates of parameters dictating OA volatility are highly uncertain (Cappa and Jimenez, 2010). Thermodenuder (TD) systems have been previously applied to measure ambient-OA volatility (Burtscher et al., 2001; Huffman et al., 2009; Lee et al., 2010; Paciga et al., 2016; $\mathrm{Xu}$ et al., 2016). A TD system measures evaporation of sampled aerosol at various temperature perturbations by systematically comparing the size distribution and/or aerosol mass concentration measured after heating in a TD and at a reference ("bypass") condition (Huffman et al., 2008). Several efforts have been made to infer ambient-OA volatility distributions by fitting observed evaporation in a TD using a model of evaporation kinetics (Cappa and Jimenez, 2010; Lee et al., 2010). However, since OA evaporation in a TD is dictated by a large number of independent parameters (e.g., $C^{*}, \Delta H_{\mathrm{vap}}$, and $\gamma_{\mathrm{e}}$ ) (Cappa and Jimenez, 2010; Lee et al., 2010), it is difficult to constrain all parameters with a onedimensional perturbation (e.g., varying TD temperature) to the initial equilibrium. Saha et al. (2015) showed that operating two TDs in parallel (dual-TD), varying both temperature and residence time, can provide tighter constraint on estimates of volatility parameter values $\left(C^{*}, \Delta H_{\mathrm{vap}}\right.$, and $\left.\gamma_{\mathrm{e}}\right)$ for single-component OA via kinetic model fits to the observations. In Saha and Grieshop (2016), this approach was applied to determine volatility and phase-partitioning parameter values for laboratory $\alpha$-pinene SOA. The resulting parameters are consistent with recent observations of low-volatility SOA (Jokinen et al., 2015; Zhang et al., 2015) and evaporation rates (Vaden et al., 2011; Wilson et al., 2015) observed by several techniques. TD perturbations alone cannot give insights into the solubility of OA components, though they may be used to do so in concert with other techniques (Cerully et al., 2015).

This paper describes the application of the dual-TD approach during ambient observations from two different settings in the southeastern US. Measurements at a rural site during the Southern Oxidant and Aerosol Study (SOAS2013) (https://soas2013.rutgers.edu/) leverage the range of complementary measurements available during this large field study. To provide a contrast, measurements were also taken several months later under cooler conditions in Raleigh, US, a small metropolitan area in a similar ecological zone but with stronger influence from local anthropogenic emissions. The objectives of the study were to (i) determine a set of volatility parameter values, such as OA volatility distribution using the volatility basis set (VBS) framework (Donahue et al., 2006, 2012), $\Delta H_{\text {vap }}$, and $\gamma_{\mathrm{e}}$, that describe observations; (ii) examine the variability and consistency in ambient-OA volatility distributions across diverse settings and conditions; (iii) examine relationships between extracted volatility distributions and OA composition and source contributions; and (iv) evaluate a model treatment of OA volatility by comparing the measured OA volatility distribution 
with that simulated by a chemical transport model using a current implementation of the VBS framework.

\section{Methods}

\subsection{Measurement sites}

Ambient OA volatility measurements were conducted at two locations in the southeastern US, one in a forested rural setting and another in an urban location. During the Southern Oxidant and Aerosol Study (SOAS-2013) field campaign, 6 weeks (1 June to 15 July 2013) of continuous measurements were conducted in rural Alabama. The SOAS field campaign occurred in summer 2013 at several locations in the southeastern US in order to study the interaction of biogenic and anthropogenic atmospheric compounds with a focus on BVOCs and organic aerosols. The measurements reported here are from the main SOAS ground site $\left(32.903^{\circ} \mathrm{N}\right.$, $87.250^{\circ} \mathrm{W}$ ) near Talladega National Forest and Centreville, Alabama. The Centreville, Alabama, site is an ideal location to study volatility of OA dominated by secondary OA from BVOC precursors (Warneke et al., 2010) in the presence of a range of anthropogenic influences. An additional 4 weeks (18 October to 20 November 2013) of ambient-OA volatility measurements were conducted at the North Carolina State University (NCSU) main campus $\left(35.786^{\circ} \mathrm{N}, 78.669^{\circ} \mathrm{W}\right)$ in Raleigh, US. The NCSU site, while in an area with plentiful tree cover and BVOC emissions, receives a substantially stronger influence from anthropogenic emissions due to its location within the Raleigh metro area. Section 3.1 includes further comparison between two study areas. Hereafter, the two datasets are referred to as Centreville and Raleigh.

\subsection{Dual-thermodenuder operation and sampling strategy}

Measurements were collected using the dual-TD experimental setup introduced in Saha et al. (2015) and are only briefly described here. Two TDs operated in parallel, one at various temperature settings (temperature stepping TD, TS-TD) with a fixed, relatively longer residence time (Rt) and another at fixed temperature and various Rt settings (variable residence time TD, VRT-TD). The TS-TD temperature settings were $40,60,90,120,150$, and $180^{\circ}$ with $\sim 50 \mathrm{~s} \mathrm{Rt}$, while the VRTTD operated at 60 or $90^{\circ}$ with Rt varying between 1 and $40 \mathrm{~s}$ (five to eight settings). All Rts reported here are calculated assuming plug flow at room temperature. Temperature effects on Rt were included during modeling of evaporation kinetics (discussed below) as $\operatorname{Rt}\left(T_{\mathrm{TD}}\right)=\operatorname{Rt}\left(T_{\text {ref }}\right) \times\left(T_{\text {ref }} / T_{\mathrm{TD}}\right)$, where $T_{\text {ref }}$ and $T_{\mathrm{TD}}$ are the reference temperatures (e.g., room temperature) and TD temperature in $\mathrm{K}$, respectively (Cappa, 2010). The time to run through all temperatures and Rt steps during measurements was $\sim 4-5 \mathrm{~h}$.

A schematic of the experimental setup is shown in Fig. 1. Three scanning mobility particle sizers (SMPS, TSI Inc,

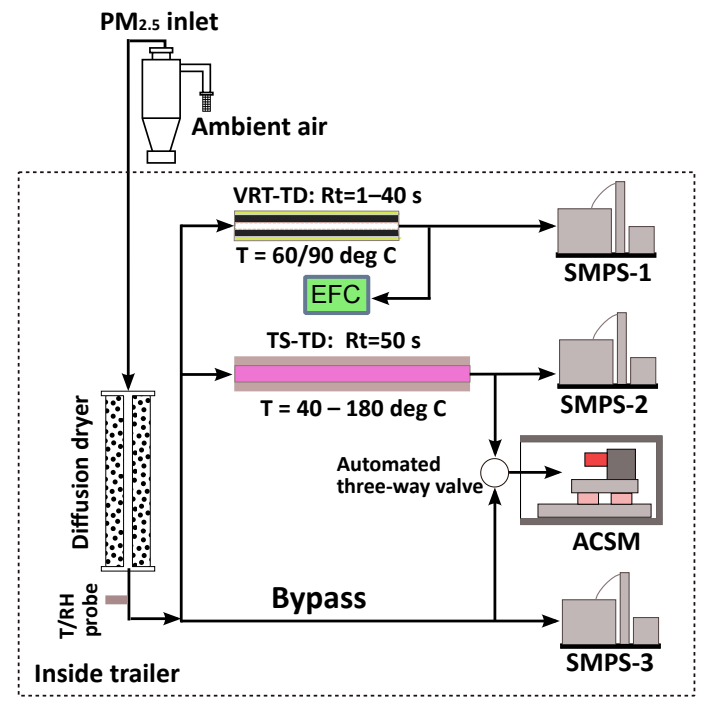

Figure 1. Dual-thermodenuder aerosol volatility measurement setup used during field campaigns at two sites in the southeastern US. TS-TD: temperature stepping TD, VRT-TD: variable residence time TD, Rt: residence time, EFC: extra flow control, ACSM: aerosol chemical speciation monitor, SMPS: scanning mobility particle sizer.

Model 3081 DMAs, Model 3010/3787 CPCs) simultaneously measured aerosol size distributions $(10-600 \mathrm{~nm})$ in three parallel lines (two TDs and one bypass). An aerosol chemical speciation monitor (ACSM, Aerodyne Research Inc.) alternated between the bypass and TS-TD lines at $\sim 20$ 30 min intervals using an automated three-way valve system. The ACSM measured the submicron aerosol $(\sim 75-650 \mathrm{~nm})$ mass concentration of nonrefractory chemical species (organic, sulfate, nitrate, ammonium, and chloride) (Ng et al., 2011a).

All aerosol instruments and TD inlets were inside a temperature-controlled $\left(25^{\circ} \mathrm{C} \pm 2\right)$ trailer in Centreville and laboratory room in Raleigh. Ambient air was continuously sampled through a sampling inlet located on the rooftop of a trailer or building ( $\sim 5 \mathrm{~m}$ above ground level). The sampling inlet included a $\mathrm{PM}_{2.5}$ cyclone (URG Corp, $16.7 \mathrm{~L} \mathrm{~min}^{-1}$ ) followed by an $\sim 8 \mathrm{~mm}$ inner diameter copper sample line. A silica gel diffusion dryer upstream of TD inlets and aerosol instruments maintained relative humidity $(\mathrm{RH})<30-40 \%$. The dryer is required for instrument operation under humid ambient conditions but may induce some loss of watersoluble OA components (El-Sayed et al., 2016).

\subsection{Quantifying OA evaporation}

Evaporation of bulk OA at a particular TD operating temperature and residence time is described in terms of mass fraction remaining (MFR). OA MFR is the ratio of OA mass concentration measured after passing through TD to that measured via the bypass (room temperature) line. For quantita- 
tive assessment of aerosol volatility, such as during modeling of aerosol evaporation, the initial OA concentration $\left(C_{\mathrm{OA}}\right)$ and particle size are also needed. Empirically estimated particle loss correction factors as a function of TD temperatures and residence times (Saha et al., 2015) and instrumental inter-calibration factors were applied in MFR calculations. To get directly comparable SMPS concentration data from three SMPSs running in parallel with our dual-TD system, we ran them periodically in parallel on the bypass line to determine intercalibration factors. Further details on SMPS intercomparison are discussed in Saha et al. (2015). Since the VRT-TD line was only measured with the SMPS (Fig. 1), it only provided information on evaporation of submicron aerosol in terms of its volume concentration. We estimated the OA MFR from VRT-TD and SMPS data assuming measured aerosol volume was only comprised of OA and ammonium sulfate (AS). This is a reasonable assumption under these conditions because more than $90 \%$ of measured aerosol volume concentrations can be explained by $\mathrm{OA}+\mathrm{AS}$ for both sites (see Supplement, Fig. S1). Our calculations also assumed that AS did not evaporate at the VRT-TD operating temperatures $\left(60\right.$ or $90^{\circ} \mathrm{C}$ ) (Fig. S2). For further details on the estimation of approximate OA MFR from VRT-TD and SMPS data, see Sect. S1.

\subsection{Determining OA gas-particle partitioning parameters}

We apply a previously described volatility parameter extraction framework (Saha et al., 2015; Saha and Grieshop, 2016) to extract a set of volatility parameter $\left(C^{*}, \Delta H_{\mathrm{vap}}, \gamma_{\mathrm{e}}\right)$ values via inversion of dual-TD data using an evaporation kinetics model. The evaporation kinetics model used here is that described in Lee et al. (2011). The approach is briefly outlined below. The resulting fit describes OA using a $\log _{10}$ volatility basis set (VBS) framework (Donahue et al., 2006, 2012), where material is lumped into volatility bins separated by orders of magnitude in $C^{*}$ space at a reference temperature $\left(T_{\text {ref }}\right)$. The volatility distribution extracted using this approach is an empirical estimate describing the bulk volatility behavior of OA, assuming absorptive partitioning (Donahue et al., 2006, 2012). The VBS approach is based on an effective saturation concentration $\left(C^{*}\right)$ where the activity coefficient is assumed to be lumped into the saturation concentration. In the VBS approach, total OA concentration $\left(C_{\mathrm{OA}}\right.$; $\left.\mu \mathrm{g} \mathrm{m}^{-3}\right)$ is modeled using Eq. (1).

$C_{\mathrm{OA}}=C_{\mathrm{tot}} \sum_{i} f_{i}\left(1+\frac{C_{i}^{*}}{C_{\mathrm{OA}}}\right)^{-1}$

Here, $C_{\text {tot }}$ is the total organic material (vapor + aerosol) in phase equilibrium with $C_{\mathrm{OA}}$ and $f_{i}$ is the fraction of $C_{\mathrm{tot}}$ in each volatility $\left(\log _{10} C^{*}\right)$ bin. Thus, $f_{i}=C_{\text {tot, } \mathrm{i}} / C_{\text {tot }}$ describes the distribution of organics in volatility space and is usually called the volatility distribution.
The Clausius-Clapyeron equation (Eq. 2) is used to represent temperature-dependent $C^{*}$.

$C_{i}^{*}(T)=C_{i}^{*}\left(T_{\text {ref }}\right) \exp \left[-\frac{\Delta H_{\mathrm{vap}, i}}{R}\left(\frac{1}{T}-\frac{1}{T_{\mathrm{ref}}}\right)\right] \frac{T_{\mathrm{ref}}}{T}$,

where $R$ is the gas constant and $\Delta H_{\text {vap }}$ is the enthalpy of vaporization.

To extract the volatility distribution of OA from ambient measurements, we select lower- and upper- $C^{*}\left(T_{\text {ref }}\right)$ bins of $10^{-4}$ and $10^{1} \mu \mathrm{g} \mathrm{m}^{-3}$, respectively. A reference temperature $\left(T_{\text {ref }}\right)$ of $298 \mathrm{~K}$ is assumed. All $C^{*}$ values reported in this paper should be considered at $298 \mathrm{~K}$, unless otherwise specified. The selection of the lower and upper bins are determined by the highest TD operating temperature $\left(180^{\circ} \mathrm{C}\right)$ and the average ambient-OA loading $\left(C_{\mathrm{OA}} \sim\right.$ $5 \mu \mathrm{g} \mathrm{m}^{-3}$ ), respectively. With these $C^{*}$ bin limits, materials with $C^{*}<10^{-4} \mu \mathrm{g} \mathrm{m}^{-3}$ are lumped into the lowest bin, while materials with $C^{*}>10 \mu \mathrm{g} \mathrm{m}^{-3}$ are not represented. Note, if a $C^{*}$ bin of $100 \mu \mathrm{g} \mathrm{m}^{-3}$ is included, Eq. (1) indicates that less than $5 \%$ of the material in this bin will be in the condensed phase at $C_{\mathrm{OA}} \sim 5 \mu \mathrm{g} \mathrm{m}^{-3}$. Therefore, $C^{*}$ bins $>10 \mu \mathrm{g} \mathrm{m}^{-3}$ are not well constrained by our TD data and are not included in our analysis.

The general approach to fitting a volatility parameterization employed in this study is similar to that applied to laboratory aerosol systems (Saha et al., 2015; Saha and Grieshop, 2016). Briefly, the kinetic model tracks both particle- and gas-phase concentrations of model species (each represented by a VBS bin) as they proceed through TD operated at a particular temperature and residence time. The model takes inputs of several aerosol properties (e.g., $C^{*}$ distribution, $\Delta H_{\text {vap }}$, diffusion coefficient $(D)$, surface tension $(\sigma)$, molecular weight (MW), and density $(\rho)$ ), total aerosol loading $\left(C_{\mathrm{OA}}\right)$, and particle diameter $\left(d_{\mathrm{p}}\right)$ and determines how much aerosol mass concentration will evaporate for a set of input parameters at a particular TD temperature and residence time. Non-continuum effects on mass transfer are represented using the Fuchs-Sutugin correction factor, which depends on $\gamma_{\mathrm{e}}$. The model is applied to extract OA properties such as the volatility distribution, $\Delta H_{\mathrm{vap}}$, and $\gamma_{\mathrm{e}}$ as fitting parameters by matching measured and modeled evaporation data. Values of $D, \sigma, \mathrm{MW}$, and $\rho$ generally have a smaller influence on observed evaporation (Cappa and Jimenez, 2010; Saha et al., 2015) and are approximated from literature values (Table S1). Volume median diameter was used as a representative $d_{\mathrm{p}}$. For simplicity, a large $\left(\Delta H_{\mathrm{vap}}, \gamma_{\mathrm{e}}\right)$ space was considered for fitting a $f_{i}$ distribution of measured OA. Following previous work (Epstein et al., 2010; May et al., 2013), a linear relationship was assumed between $\Delta H_{\text {vap }}$ and $\log _{10} C^{*}$ with $\Delta H_{\text {vap }, i}=$ intercept-slope $\left(\log _{10} C_{i, 298}^{*}\right)$, where intercept and slope are fit parameters. Values for $\Delta H_{\text {vap }}$ intercept $=[50,80,100,130,200]$ and slope $=[0,4,8$, $11] \mathrm{kJ} \mathrm{mol}^{-1}$ were applied along with $\gamma_{\mathrm{e}}=[0.01,0.05,0.1$, $0.25,0.5,1] . \gamma_{\mathrm{e}}$ was assumed constant over all bins and is an 
effective parameter representing all kinetic limitations within the condensed phase and at the particle surface.

A distribution of $f_{i}$ was solved for each combination of $\left(\Delta H_{\mathrm{vap}}, \gamma_{\mathrm{e}}\right)$ applying the nonlinear constrained optimization solver "fmincon" in MATLAB (Mathworks, Inc.) by first fitting TS-TD data; accepted solutions were then further refined by fitting VRT-TD observations. A constraint of $\Sigma f_{i}=1$ was used. The goodness of fit was quantified in terms of the sum of squared residual (SSR) values. For the campaign-average fit, an acceptance threshold value for SSR was selected based on observed variability ( \pm one standard deviation) in measurements. A parameter set $\left(f_{i}, \Delta H_{\mathrm{vap}}\right.$, and $\left.\gamma_{\mathrm{e}}\right)$ was considered a finally accepted solution if it optimally reproduced both TS-TD and VRT-TD observations within the observed variability. Raw data at each $(T, \mathrm{Rt})$ condition were averaged over 20-30 min. At given TD operating conditions $(T, \mathrm{Rt})$, we defined \pm 1 standard deviation of MFR data (20-30 min resolution) from the whole campaign as an indicator of the observed variability. The best fit is defined as that with the lowest SSR value among all the accepted combinations.

\subsection{Simulation of OA in a chemical transport model}

Considering that VBS-based parameterizations are becoming common means to improve the performance of OA prediction in chemical transport models (CTMs) (Farina et al., 2010; Lane et al., 2008b; Matsui et al., 2014; Murphy et al., 2011; Shrivastava et al., 2013), measurements of OA volatility provide a useful means by which to evaluate these simulations. We compared OA volatility distributions measured in this study to those resulting from CTM simulations using a current VBS-based parameterization implemented in a modified version of the Weather, Research and Forecasting model with Chemistry (WRF/Chem) v3.6.1 (Wang et al., 2015; Yahya et al., 2016). The WRF/Chem simulation uses the Carbon Bond version 6 (CB6) gas-phase mechanism (Yarwood et al., 2010) coupled by Wang et al. (2015) to the Model for Aerosol Dynamics for Europe - Volatility Basis Set (MADE/VBS) (Ackermann et al., 1998; Ahmadov et al., 2012; Shrivastava et al., 2011). The CB6-MADE/VBS treatment includes semivolatile POA and SOA, as well as a fragmentation and functionalization treatment for multigenerational OA aging based on Shrivastava et al. (2013). The fragmentation and functionalization treatment in this case assumes $25 \%$ fragmentation for the third and higher generations of oxidation (Shrivastava et al., 2013). The ranges of $C^{*}$ values used in WRF/Chem simulation are defined based on current SOA and semivolatile POA parameterizations and were $10^{0}$ to $10^{3} \mu \mathrm{g} \mathrm{m}^{-3}$ for ASOA (anthropogenic SOA) and BSOA (biogenic SOA), $10^{-2}$ to $10^{6} \mu \mathrm{g} \mathrm{m}^{-3}$ for POA and $10^{-2}$ to $10^{5} \mu \mathrm{g} \mathrm{m}^{-3}$ for SVOA (semivolatile OA), where SVOA refers to oxidized OA from evaporated POA. The semiempirical correlation for $\Delta H_{\mathrm{vap}}$ by Epstein et al. (2010) was used to estimate temperature-dependent partitioning.
The simulations are performed at a horizontal resolution of $36 \mathrm{~km}$ with $148 \times 112$ horizontal grid cells over the continental US domain and parts of Canada and Mexico and a vertical resolution of 34 layers from the surface to $100 \mathrm{hPa}$. Anthropogenic emissions in 2010 were based on the 2008 National Emissions Inventory (NEI) from the Air Quality Model Evaluation International Initiative (AQMEII) project (Pouliot et al., 2015). Biogenic emissions are simulated online by the Model of Emissions of Gases and Aerosols from Nature v2.1 (MEGAN2.1) (Guenther et al., 2012). The chemical initial and boundary conditions (ICs and BCs) come from the modified Community Earth System Model/Community Atmosphere Model (CESM/CAM v5.3) with updates by He and Zhang (2014) and Gantt et al. (2014). The meteorological ICs and BCs come from the National Center for Environmental Protection Final Analysis (FNL) data.

\section{Results}

\subsection{Overview of campaign characteristics}

The two field campaigns were conducted in settings with distinct local emission sources and metrological conditions. The Centreville campaign was during summer $(T=24.7 \pm$ $3.3{ }^{\circ} \mathrm{C}, \mathrm{RH}=83.1 \pm 15.3 \%$ ). Local organic emissions surrounding the Centreville site are dominated by BVOCs since this site is located in a forest and biogenic emissions substantially increase with temperature (Lappalainen et al., 2009; Tarvainen et al., 2005; Warneke et al., 2010). In contrast, Raleigh measurements were in a setting with substantially stronger anthropogenic emissions during fall and winter $\left(T=12.7 \pm 6.0^{\circ} \mathrm{C}, \mathrm{RH}=65.7 \pm 18.8 \%\right)$. Comparison of long-term data from an air quality monitoring station near the Raleigh site shows substantially higher $\mathrm{NO}_{x}$ (5-10-fold) and $\mathrm{CO}$ (2-4-fold) concentrations relative to those observed at Centreville (see Fig. S3). However, the Raleigh-Durham metropolitan area has plentiful tree cover and thus substantial local BVOC emissions. For instance, $\alpha$ - and $\beta$-pinene concentrations measured in summer at Centreville and Duke Forest (about $40 \mathrm{~km}$ northwest of the Raleigh site) are in the same range (Fig. S4). However, since the Raleigh campaign was conducted at lower temperature conditions, local BVOC emissions are expected to be lower by a factor of 3 to 4 (Fig. S4). Measurements in such diverse but similar ecological settings allow us to examine the consistency of OA volatility under varying levels of biogenic and anthropogenic influence.

Figures S5-S7 show average meteorological conditions, submicron aerosol size distributions, chemical composition, and their temporal variations over the campaign periods. Ambient submicron particle number concentrations $(10-600 \mathrm{~nm})$ were higher in Raleigh (Centreville: 1500 $3000 \mathrm{~cm}^{-3}$, Raleigh: $3000-6000 \mathrm{~cm}^{-3}$ ) and particle size was relatively smaller (volume median diameter, Centre- 
ville: $275 \pm 30 \mathrm{~nm}$, Raleigh: $227 \pm 34 \mathrm{~nm}$ ) (Fig. S6). Organic species were the dominant component in nonrefractory submicron aerosol $\left(\mathrm{PM}_{1}\right)$ as measured by the ACSM at both sites (Centreville: $71 \pm 10 \%$, Raleigh: $76 \pm 8 \%$ ). The campaign average \pm 1 standard deviation of ACSM-derived OA mass concentrations was $5.2 \pm 3.0 \mu \mathrm{g} \mathrm{m}^{-3}$ in Centreville and $6.7 \pm 3.6 \mu \mathrm{g} \mathrm{m}^{-3}$ in the Raleigh campaign, assuming a collection efficiency (CE) of 0.5. After applying the coarse tracer $(m / z)$-based factor analysis approach to decompose OA mass spectra (Ng et al., 2011b), the majority of OA measured at both sites was oxygenated OA (OOA). While approximately $7 \%$ of campaign-averaged OA mass concentration in Raleigh was classified as hydrocarbon-like OA (HOA), the HOA contribution at the Centreville site was negligible. Positive matrix factorization (PMF) results from high-resolution mass spectra collected at the Centreville site (Xu et al., 2015a, b) and their linkage with the measured OA volatility are discussed in Sect. 3.3 and 3.4 below.

\subsection{Observed campaign-average evaporation of $\mathrm{OA}$}

Figure 2 shows the campaign-average OA MFR as a function of TD temperature and residence time. (1-MFR) at a TD temperature and residence time indicates what fraction of bulk OA mass evaporates at that condition. It is important to note that MFR at a given temperature is not a consistent descriptor of OA volatility because it depends on many parameters related to TD experimental conditions (e.g., Rt) and sampled aerosol (e.g., $C_{\mathrm{OA}}, d_{\mathrm{p}}$ ). Therefore, MFR data should not be interpreted as a direct measure of OA volatility or even directly compared (unless experiments are conducted under identical conditions).

Figure 2a (MFR vs. temperature, frequently called a thermogram plot) shows TS-TD measurements from this study along with one other measurement from SOAS (Hu et al., 2016) and several previous field and laboratory measurements. The campaign-average OA MFRs measured at the two sites in the southeastern US, under relatively consistent $C_{\mathrm{OA}} \sim 5 \mu \mathrm{g} \mathrm{m}^{-3}$, were found to be quite similar. Approximately $60-70 \%$ of OA mass evaporated after heating at $100^{\circ} \mathrm{C}$ with a residence time of $50 \mathrm{~s}$. The campaignaverage $T_{50}$ and $T_{90}$ (temperature at which 50 and $90 \%$ of OA mass evaporates, respectively) with a residence time of $50 \mathrm{~s}$ were $\sim 78$ and $\sim 180^{\circ} \mathrm{C}$, respectively. Data from $\alpha$ pinene chamber SOA experiments collected using the same dual-TD setup at atmospheric conditions (dark ozonolysis, $C_{\mathrm{OA}} \sim 5 \mu \mathrm{g} \mathrm{m}^{-3}$ ), described in Saha and Grieshop (2016), are also shown. Relative to the ambient observations, the lab SOA data show similar evaporation behavior in the lower temperature range $\left(40-90^{\circ} \mathrm{C}\right)$ but relatively greater evaporation at higher temperatures.

Figure $2 \mathrm{~b}$ and $\mathrm{c}$ show the campaign-average-estimated $\mathrm{OA}$ MFRs at various residence times with the VRT-TD operated at 60 and $90^{\circ} \mathrm{C}$, respectively. Results show increased evaporation with longer residence time. In Fig. 2a, data are color
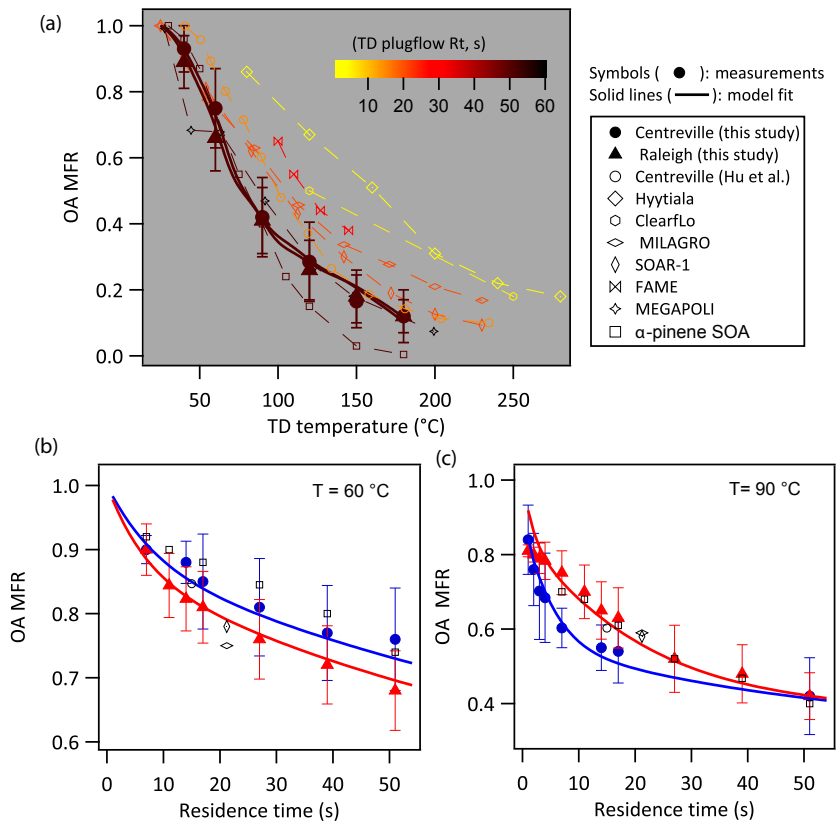

Figure 2. Measured (solid symbols) and modeled (solid, thick lines) campaign-average organic aerosol (OA) mass fraction remaining (MFR) as a function of TD temperatures $(T)$ and residence times (Rt). The solid symbol shows mean value and the error bar is \pm one standard deviation of all campaign data at each $(T, \mathrm{Rt})$ condition. Model lines are shown using the best fit volatility parameter values from campaign-average TD data fit (parameter values listed in Table 1). TD measurement data from the Centreville site collected by the University of Colorado group at SOAS-2013 (Hu et al., 2016) are also shown. Measurements from several previous field studies are shown with various open symbols: Hyytiala/2008-2010, Finland (Häkkinen et al., 2012); ClearfLo/2012, London (Xu et al., 2016); MILAGRO/2006, Mexico City (Huffman et al., 2009); SOAR-1/2005, Riverside, California (Huffman et al., 2009); FAME/2008, Finokalia, Greece (Lee et al., 2010); MEGAPOLI/2009-2010, Paris, France (Paciga et al., 2016). Chamber $\alpha$-pinene SOA (dark ozonolysis, $C_{\mathrm{OA}} \sim 5 \mu \mathrm{g} \mathrm{m}^{-3}$, VMD $\sim 140 \mathrm{~nm}$ ) evaporation data are shown from Saha and Grieshop (2016). In panel (a), data are color coded by TD residence times used during measurements. The legend shown next to panel (a) applies to all panels (a-c).

coded by the TD residence time used in each study. A substantial effect of residence time on the observed evaporation is consistent with that observed across TD measurements from several previous field studies (Häkkinen et al., 2012; Huffman et al., 2009; Lee et al., 2010; Paciga et al., 2016; Xu et al., 2016). This effect of residence time on observed MFR strongly suggests that comparisons of OA volatility across studies should not be made based on measured MFRs. Doing so may bias inferences about differences in aerosol volatility. Observed evaporation depends on TD residence time and many physical and chemical properties of sampled aerosol (Cappa, 2010; Riipinen et al., 2010; Saleh et al., 2011), unless the aerosol reaches equilibrium inside a TD (saturates 
Table 1. Best fit OA volatility parameter values extracted from this study along with several previous field and lab studies.

\begin{tabular}{|c|c|c|c|c|c|c|c|c|c|c|c|}
\hline \multirow{2}{*}{$\begin{array}{l}\text { Study } \\
\begin{array}{l}\text { Campaign average } \\
C_{\mathrm{OA}}\left(\mu \mathrm{g} \mathrm{m}^{-3}\right)\end{array}\end{array}$} & \multicolumn{2}{|c|}{$\begin{array}{l}\text { Centreville } \\
\text { (this study) }\end{array}$} & \multicolumn{2}{|c|}{$\begin{array}{c}\text { Raleigh } \\
\text { (this study) }\end{array}$} & \multicolumn{2}{|c|}{$\begin{array}{c}\text { FAME } \\
\text { (Lee et al., 2010) }\end{array}$} & \multicolumn{4}{|c|}{$\begin{array}{l}\text { MILAGRO (Cappa and } \\
\text { Jimenez, 2010) }\end{array}$} & \multirow{2}{*}{$\begin{array}{r}\text { AP-SOA (Saha and } \\
\text { Grieshop, 2016) } \\
5\end{array}$} \\
\hline & \multicolumn{2}{|c|}{5.2} & \multicolumn{2}{|c|}{6.7} & \multicolumn{2}{|c|}{2.8} & \multicolumn{4}{|c|}{17} & \\
\hline Note & $\mathrm{a}$ & $\mathrm{b}$ & $\mathrm{a}$ & $\mathrm{b}$ & & & $\mathrm{c}$ & $\mathrm{d}$ & $\mathrm{c}$ & $\mathrm{d}$ & $\mathrm{e}$ \\
\hline$\gamma_{\mathrm{e}}$ & 0.5 & 0.5 & 0.5 & 0.5 & 0.05 & 1 & 1 & 1 & 0.1 & 0.1 & 0.1 \\
\hline$\Delta H_{\mathrm{vap}}\left(\mathrm{kJ} \mathrm{mol}^{-1}\right)$ & 100 & 100 & 100 & 100 & 80 & 80 & 100 & 100 & 100 & 100 & {$[80,11]^{\mathrm{f}}$} \\
\hline \multicolumn{7}{|l|}{$\log C^{*}\left(\mu \mathrm{g} \mathrm{m}^{-3}\right)$} & \multicolumn{5}{|c|}{$f_{i}$} \\
\hline $\begin{array}{l}-6 \\
-5 \\
-4 \\
-3 \\
-2 \\
-1 \\
0 \\
1 \\
2\end{array}$ & $\begin{array}{l}0.14 \\
0.05 \\
0.06 \\
0.15 \\
0.29 \\
0.31\end{array}$ & $\begin{array}{l}0.18 \\
0.05 \\
0.08 \\
0.13 \\
0.33 \\
0.23\end{array}$ & $\begin{array}{l}0.14 \\
0.06 \\
0.08 \\
0.12 \\
0.28 \\
0.32\end{array}$ & $\begin{array}{l}0.16 \\
0.05 \\
0.13 \\
0.20 \\
0.20 \\
0.26\end{array}$ & $\begin{array}{l}0.2 \\
0.2 \\
0.3 \\
0.3\end{array}$ & $\begin{array}{l}0.2 \\
0.2 \\
0.3 \\
0.3\end{array}$ & $\begin{array}{l}0.06 \\
0.06 \\
0.06 \\
0.07 \\
0.07 \\
0.08 \\
0.10 \\
0.16 \\
0.34\end{array}$ & $\begin{array}{l}0.27 \\
0.11 \\
0.11 \\
0.12 \\
0.15 \\
0.24\end{array}$ & $\begin{array}{r}0.04 \\
0.04 \\
0.04 \\
0.04 \\
0.05 \\
0.06 \\
0.1 \\
0.2 \\
0.43\end{array}$ & $\begin{array}{l}0.21 \\
0.07 \\
0.09 \\
0.10 \\
0.18 \\
0.35\end{array}$ & $\begin{array}{l}0.03 \\
0.07 \\
0.03 \\
0.12 \\
0.18 \\
0.57\end{array}$ \\
\hline Mean $C^{*}\left(\mu \mathrm{g} \mathrm{m}^{-3}\right)$ & 0.21 & 0.12 & 0.20 & 0.10 & 0.50 & 0.05 & 0.32 & 0.03 & 1.5 & 0.1 & 1.16 \\
\hline$C_{\mathrm{eff}}^{*}\left(\mu \mathrm{g} \mathrm{m}^{-3}\right)$ & 1.8 & 1.4 & 2.0 & 1.5 & 1.3 & 0.3 & 9.4 & 1.9 & 13.8 & 2.8 & 3.5 \\
\hline $\begin{array}{l}\text { Campaign-average dual-TD } \\
\text { b Unified fit of individual me } \\
\text { The } f_{i} \text { distribution derived } \\
\text { Jimenez (2010). } \log _{10} C^{*} \text { bin } \\
\text { d Same as }{ }^{\mathrm{c}} \text {, but only conside } \\
\text { assigned to }-4 \text { bin, material } \\
\text { Chamber-generated SOA fr } \\
\text { and Grieshop }(2016) \text { Suppler } \\
\Delta H_{\text {vap }}\left(\mathrm{kJ} \mathrm{mol}^{-1}\right)=80-\end{array}$ & $\begin{array}{l}\text { data fit w } \\
\text { surement } \\
\text { rom } C_{i, \text { to }} \\
\text { anged fr } \\
\text { ed } \log _{10} \\
\log _{10} C^{*} \\
\text { m low- } C \\
\text { ent, Tabl } \\
\log C^{*}\end{array}$ & $\begin{array}{l}\text { th camp } \\
\text { from w } \\
=a_{1}+ \\
\mathrm{n}-6 \text { to } \\
* \text { bin ra } \\
=2 \text { bin } \\
\text { A } \alpha \text {-pin } \\
\text { S5. } \\
\left.\mathrm{g} \mathrm{m}^{-3}\right) .\end{array}$ & $\begin{array}{l}\text { gn-avera } \\
\text { le camp } \\
\text { exp }\left[a_{3}(\right. \\
2 \text {, as in } \\
\text { e of }-4 \\
\text { exclude } \\
\text { e ozonol }\end{array}$ & $\begin{array}{l}C_{\mathrm{OA}} \text { at } \\
\mathrm{gn}(\mathrm{MFF} \\
\mathrm{g}\left(C^{*}\right)- \\
\text { appa anc } \\
+1 \text { to } \\
\text { and dist } \\
\text { sis exper }\end{array}$ & $\begin{array}{l}d_{\mathrm{p}} \\
C_{\mathrm{OA}}, d_{\mathrm{p}} \\
\text { )]; } f_{i}= \\
\text { Jimenez ( } \\
\text { consister } \\
\text { bution is } \\
\text { nent appl }\end{array}$ & $\begin{array}{l}\text { e bin } \\
\text { ized } \\
\text { rmal }\end{array}$ & $\begin{array}{l}\text { ion di } \\
2 \text {, an } \\
\text { es use } \\
\text { ke } \Sigma \\
\text { n app }\end{array}$ & $\begin{array}{l}3 \text { coef } \\
\text { this } \\
=1 \text {. }\end{array}$ & nts we & ma & $\begin{array}{l}\text { Table } 1 \text { of Cappa and } \\
\text { in } \log _{10} C^{*}<-4 \text { bins are } \\
\text { istribution given in Saha }\end{array}$ \\
\hline
\end{tabular}

the gas phase across the volatility range). The equilibration time of aerosol in a TD is dictated by many parameters, including particle size distribution, diffusion coefficient $(D)$, and evaporation coefficient $\left(\gamma_{\mathrm{e}}\right)$ and is typically several minutes or more under atmospheric (low $C_{\mathrm{OA}}$ ) conditions (Saleh et al., 2011, 2013).

Following the method of Saleh et al. (2013), the estimated characteristic equilibration times for the sampled aerosol in the Centreville and Raleigh measurements are 147-470 and 150-450 s, respectively, assuming unhindered mass transfer $\left(\gamma_{\mathrm{e}}=1\right)$. These calculations are based on the interquartile ranges of particle number concentrations $\left(N_{p}\right)$ and condensation sink diameter $\left(d_{\mathrm{cs}}\right)$ measured in Centreville $\left(N_{\mathrm{p}} \sim 1500\right.$ $\left.3000 \mathrm{~cm}^{-3}, d_{\mathrm{cs}} \sim 125-170 \mathrm{~nm}\right)$ and Raleigh $\left(N_{\mathrm{p}} \sim 3000\right.$ $\left.6000 \mathrm{~cm}^{-3}, d_{\mathrm{cs}} \sim 80-105 \mathrm{~nm}\right)$, and $D=3.5 \times 10^{-6} \mathrm{~m}^{2} \mathrm{~s}^{-1}$ and $\mathrm{MW}=200 \mathrm{~g} \mathrm{~mol}^{-1}$. The condensation sink diameter $\left(d_{\mathrm{cs}}\right)$ is estimated following Lehtinen et al. (2003); further detail is given in the Supplement. A factor-of-10 reduction in $\gamma_{\mathrm{e}}$ relative to ideal accommodation $\left(\gamma_{\mathrm{e}}=0.1\right)$ increases equilibration time by 1 order of magnitude. The observed continuous downward slope of MFR vs. residence time (Fig. 2b, c) suggests that equilibrium was not reached in the TD dur- ing the maximum Rt of $50 \mathrm{~s}$. This result implies that TD measurements in an ambient setting are essentially a measure of the evaporation rate of sampled aerosol, rather than one of volatility, an equilibrium thermodynamic property. Therefore, an evaporation kinetic model is needed to extract volatility parameter values from ambient TD data.

\subsection{Extracted OA volatility parameter values}

Figure 3 presents the results of the extraction process used to determine parameters dictating gas-particle partitioning $\left(f_{i}\right.$, $\left.\Delta H_{\text {vap }}, \gamma_{\mathrm{e}}\right)$; the example shown is for a fit to the Centreville campaign-average data, though the same process was conducted for all fits. Figure S8 shows a similar plot for the Raleigh dataset. Fitting results show that a broad range of $\gamma_{\mathrm{e}}(0.05$ to 1$)$ can reproduce the TS-TD observation within observed variability (i.e., error bars in Fig. 2) for several $\Delta H_{\text {vap }}$ combinations (accepted TS-TD fits are shown with filled inner circles). The inclusion of VRT-TD data provides additional constraints for parameter fitting. Only the points with white crosses (x) in Fig. 3 recreate both TD datasets; a larger-sized " $x$ " represents a better fit. Thus, VRT-TD data 


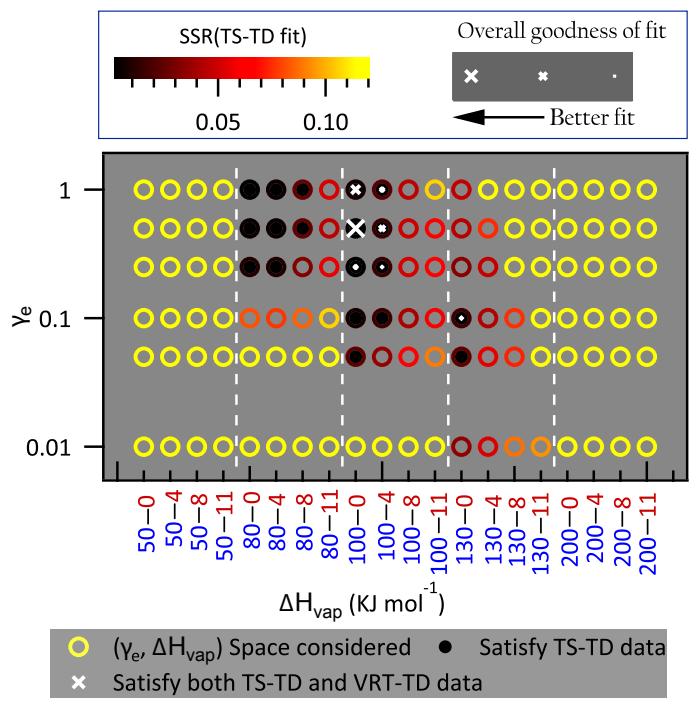

Figure 3. Extraction process of OA gas-particle partitioning parameter $\left(\Delta H_{\mathrm{vap}}, \gamma_{\mathrm{e}}\right.$ and $\left.f_{i}\right)$ values. A $f_{i}$ distribution was solved for each combination of ( $\left.\Delta H_{\mathrm{vap}}, \gamma_{\mathrm{e}}\right)$ via evaporation kinetic model fits to campaign-average dual-TD observations during the Centreville campaign. A relationship of $\Delta H_{\mathrm{vap}}=$ intercept-slope $\left(\log _{10} C^{*} @\right.$ $298 \mathrm{~K}$ ) was assumed (e.g., 50-0 on $x$ axis represents intercept $=50$ and slope $=0$ ). Symbols and colors represent the goodness of fit. Points with filled inner circles recreate TS-TD observations and points with a white cross $(\mathrm{x})$ recreate both TD datasets to within observational variability. Crosses represent the overall goodness of fit including both TS-TD and VRT-TD observations, with larger size corresponding to a better fit.

help to narrow the possible solution space. Figure 3 shows that $\Delta H_{\mathrm{vap}}=100 \mathrm{~kJ} \mathrm{~mol}^{-1}$ and $\gamma_{\mathrm{e}}=0.5$ provide the overall best fit for the Centreville dataset. For the Raleigh dataset, $\Delta H_{\text {vap }}$ of both 80 (marginally better) and $100 \mathrm{~kJ} \mathrm{~mol}^{-1}$ with $\gamma_{\mathrm{e}}=0.5$ provide similarly good fits (Fig. S8). For simplicity, $\Delta H_{\text {vap }}=100 \mathrm{~kJ} \mathrm{~mol}^{-1}$ and $\gamma_{\mathrm{e}}=0.5$ are considered as best estimates for both datasets for the next portion of the paper.

These results are inconsistent with a very small value of OA evaporation coefficient (e.g., $\left.\gamma_{\mathrm{e}} \ll 0.1\right)$ that would indicate significant resistance to mass transfer during evaporation, which has been previously suggested based on dilution (Grieshop et al., 2007, 2009; Vaden et al., 2011) and heating (Lee et al., 2011) experiments. Our best estimate of $\gamma_{\mathrm{e}} \sim 0.5$ is consistent with the observations of Saleh et al. (2012), in which they report an $\gamma_{e} \sim 0.28$ to 0.46 for ambient aerosols in Beirut, Lebanon, via measured equilibration profiles of concentrated ambient aerosols $\left(C_{\mathrm{OA}} \sim 200-300 \mu \mathrm{g} \mathrm{m}^{-3}\right)$ after heating in a TD at $60^{\circ} \mathrm{C}$. Our results show that an effective $\gamma_{\mathrm{e}} \sim 0.1$ to 1 can explain dual-TD data to within observed variability, suggesting that there is no extreme resistance to mass transfer such as what might be encountered due to a glassy-solid or highly viscous aerosol. Some previous assertions of highly inhibited evaporation (Grieshop et al., 2007; Vaden et al., 2011) were likely biased as they assumed volatility distributions based on smog-chamber yield experiments that likely overestimated the volatility and thus expected evaporation rate of lab OA (Saha and Grieshop, 2016; Saleh et al., 2013).

Our fitting results show that a $\Delta H_{\text {vap }}$ intercept of 80 $130 \mathrm{~kJ} \mathrm{~mol}^{-1}$ and slopes of 0 or $4 \mathrm{~kJ} \mathrm{~mol}^{-1}$ can be used to explain campaign-average observations (Figs. 3, S6). These $\Delta H_{\text {vap }}$ values are consistent with those of atmospherically relevant low-volatility organics such as dicarboxylic acids (Bilde et al., 2015) but distinct from those typically assumed $\left(30-40 \mathrm{~kJ} \mathrm{~mol}^{-1}\right)$ for atmospheric modeling (Farina et al., 2010; Lane et al., 2008b; Pye and Seinfeld, 2010). The low enthalpies assumed in models are based on temperaturesensitivity observations from smog chamber SOA experiments (Offenberg et al., 2006; Pathak et al., 2007; Stanier et al., 2008). The semiempirical correlation-based fit from Epstein et al. (2010) $\left(\Delta H_{\mathrm{vap}}=130-11 \log _{10} C^{*}\right)$ has steeper $\log _{10} C^{*}$ dependence than those able to explain our observations (Figs. 3, S8). The Epstein et al. (2010) correlation was determined from range of compounds with known $\Delta H_{\text {vap. }}$. Several recent studies of complex OA systems (May et al., 2013; Ranjan et al., 2012) have found that a correlation other than that from Epstein et al. (2010) better explains observations. For example, Ranjan et al. (2012) reported $\Delta H_{\text {vap }}=85-11 \log C^{*}$ for gas-particle partitioning of POA emissions from a diesel engine; May et al. (2013) reported $\Delta H_{\mathrm{vap}}=85-4 \log C^{*}$ for biomass burning POA emissions. Similar to these and other studies, our $\Delta H_{\text {vap }}$ correlation for ambient $\mathrm{OA}$ is an empirical estimate that best explains our observations.

Although several $\Delta H_{\text {vap }}$ and $\gamma_{\mathrm{e}}$ combinations can recreate observations from both TDs within variability (Figs. 3, S8), to enable comparison of $C^{*}$ distributions we adopt our best estimates of $\Delta H_{\text {vap }}$ and $\gamma_{\mathrm{e}}\left(\Delta H_{\mathrm{vap}}=100 \mathrm{~kJ} \mathrm{~mol}^{1}\right.$ and $\left.\gamma_{\mathrm{e}}=0.5\right)$ for further analysis of data from both campaigns; corresponding campaign-average $f_{i}$ distributions are the basis for model fits shown in Fig. 2. The campaign-average $f_{i}$ distribution was derived by fitting campaign-average dualTD observations (Fig. 2) and using campaign-average $C_{\mathrm{OA}}$ and $d_{\mathrm{p}}$. A $f_{i}$ distribution was also fit based on all the individual measurements from the campaign (MFR, $C_{\mathrm{OA}}, d_{\mathrm{p}}$; 20-30 min time resolution) using $\Delta H_{\text {vap }}=100 \mathrm{~kJ} \mathrm{~mol}^{-1}$ and $\gamma_{\mathrm{e}}=0.5$; we term this the unified fit. The campaign-average and unified $f_{i}$ distributions for the Centreville and Raleigh datasets are listed in Table 1 . In addition to the volatility distribution $\left(f_{i}\right)$, we also show estimates of mean $C^{*}\left(\overline{C^{*}}\right.$, estimated as $\overline{C^{*}}=10^{\left.\sum f_{i} \log _{10} C_{i}^{*}\right)}$ to quantify the center of mass (central tendency) of different volatility distributions. Another way to collapse a distribution to a single value (also reported in Table 1) is the effective $C^{*}\left(C_{\text {eff }}^{*}\right)$ of the ensemble, estimated as $C_{\mathrm{eff}}^{*}=\sum x_{i} C_{i}^{*}$, where $x_{i}$ is the condensedphase mass fraction contributed by each $C_{i}^{*}$ bin and $\Sigma x_{i}=1$. While the volatility parameter values reported in Table 1 are the best fit results, other parameter sets can reproduce observations within variability. Application of $f_{i}$ distributions 
(a)

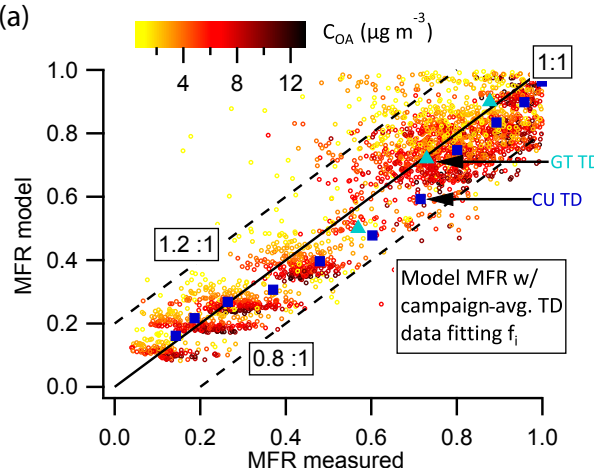

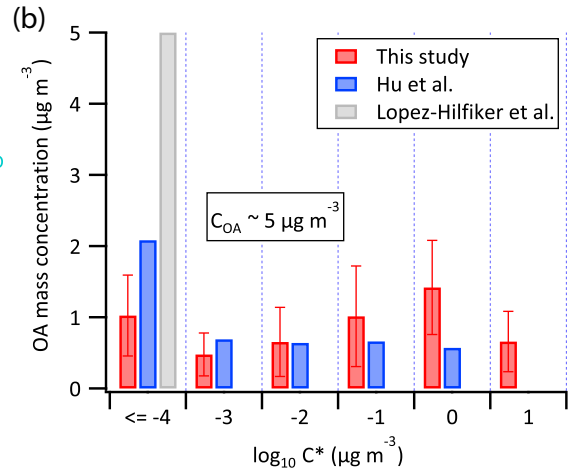

Figure 4. (a) Comparison of individual observations from the Centreville campaign and corresponding modeled MFRs applying the extracted $f_{i}$ distribution from the campaign-average fit $\left(r^{2}=0.83\right.$; RMSE: 0.11). MFR data collected by other groups during the Centreville campaign are also shown: University of Colorado TD (CU TD, blue squares) (Hu et al., 2016) and Georgia-Tech TD (GT TD, cyan triangles) (Cerully et al., 2015), along with corresponding MFRs modeled applying volatility parameterizations from this study with the campaign-average $C_{\mathrm{OA}}$ and $d_{\mathrm{p}}$. Figure $\mathrm{S} 9$ shows an extended data figure of panel (a), including a similar plot using the $f_{i}$ distribution from the unified fit and analysis results for the Raleigh dataset. (b) Comparison of the SOAS campaign-average OA volatility distribution (showing only condensed phase) derived from this study (dual TDs, kinetic evaporation model fits), Hu et al. (2016) (TD; method of Faulhaber et al., 2009), and Lopez-Hilfiker et al. (2016) (FIGAERO-CIMS). Error bars on data from this study are \pm 1 standard deviation of distributions extracted over the campaign period (Fig. 6).

reported in Table 1 must be with reported $\gamma_{\mathrm{e}}$ and $\Delta H_{\mathrm{vap}}$ values. Sensitivities of the estimated volatility parameter values to assumed values of $D, \sigma, \mathrm{MW}$, and $\rho$ are discussed in Saha et al. (2015) and Saha and Grieshop (2016). These assumed parameters have relatively minor effects on observed evaporation in a TD compared to $C^{*}, \gamma_{\mathrm{e}}$, and $\Delta H_{\mathrm{vap}}$.

The extracted campaign-average and unified-fit $\mathrm{OA}$ volatility distributions $\left(f_{i}\right)$ and corresponding $\overline{C^{*}}$ and $C_{\mathrm{eff}}^{*}$ from Centreville and Raleigh datasets are quite similar (see Table 1). A large portion of the measured OA (40-70\%) at both sites is composed of very-low-volatility organics (LVOCs, $C^{*} \leq 0.1 \mu \mathrm{g} \mathrm{m}^{-3}$; Donahue et al., 2012). It is somewhat surprising that results from two field campaigns, which occurred in distinct scenarios with varying levels of biogenic and anthropogenic emissions, result in such similar OA volatility distributions. This finding is consistent with those of Kolesar et al. (2015a), who report similar mass thermograms for laboratory SOA formed from a variety of anthropogenic and biogenic VOCs under different oxidant $\left(\mathrm{O}_{3}\right.$, $\mathrm{OH})$ conditions. Our extracted ambient-OA volatility distributions are also comparable to those previously derived from TD measurement in Mexico City (Cappa and Jimenez, 2010) and Finokalia, Greece (Lee et al., 2010). However, the ambient-OA volatility distributions determined here are relatively less volatile than those from chamber-generated fresh SOA from $\alpha$-pinene ozonolysis (Table 1).

Figure $4 \mathrm{a}$ demonstrates a forward modeling exercise to show how the extracted average volatility parameter values ( $f_{i}, \Delta H_{\text {vap }}$, and $\gamma_{\mathrm{e}}$, those listed in Table 1$)$ can reproduce individual measurements from the whole Centreville campaign as well as TD data from other groups (Cerully et al., 2015; $\mathrm{Hu}$ et al., 2016) during SOAS. The results show that a sin- gle set of volatility parameter values (campaign average fit $f_{i}, \gamma_{\mathrm{e}}=0.5$ and $\Delta H_{\mathrm{vap}}=100 \mathrm{~kJ} \mathrm{~mol}^{-1}$ ) reproduce individual observations from the whole campaign within approximately $\pm 20 \%$ (coefficient of determination, $r^{2}=0.83$; root mean squared error, RMSE $=0.11$ ). These parameter values also closely reproduced the measured campaign-average OA MFRs from the University of Colorado TD ( Rt $\sim 15 \mathrm{~s})(\mathrm{Hu}$ et al., 2016) and Georgia Tech TD (Rt $\sim 7 \mathrm{~s}$ ) (Cerully et al., 2015) collected during the Centreville campaign (see solid blue squares and cyan triangles in Fig. 4a). MFRs reported in Cerully et al. (2015) are for the total submicron aerosol species. These were converted to OA MFRs, applying the method given in Supplement Sect. S1 to enable direct comparison with modeled OA MFRs.

Figure $4 \mathrm{~b}$ shows a comparison of the extracted campaignaverage OA volatility distribution from this study with those from two other independent approaches during the Centreville campaign (Hu et al., 2016; Lopez-Hilfiker et al., 2016). $\mathrm{Hu}$ et al. (2016) report OA volatility distributions from observed evaporation in a TD during the Centreville campaign fit using the method given by Faulhaber et al. (2009). In this method, TD evaporation observations at different temperatures are translated to a volatility distribution using an empirically derived calibration curve based on evaporation of known compounds and their $C^{*}$ (Faulhaber et al., 2009). Our derived distribution from dual-TD observations coupled with evaporation kinetic model is comparable to that from $\mathrm{Hu}$ et al. (2016), although this distribution is slightly less volatile than ours. Lopez-Hilfiker et al. (2016) derived an OA volatility distribution from Centreville measurements with the FIGAERO-CIMS (Filter Inlet for Gases and AerosolsChemical Ionization Mass Spectrometer), which thermally 
desorbs filter-bound aerosol into a CIMS. The FIGAEROderived distribution is several orders of magnitude less volatile than ours; all OA in it has $C^{*} \leq 10^{-4} \mu \mathrm{g} \mathrm{m}^{-3}$. Therefore, in Fig. $4 \mathrm{~b}$ the Centreville campaign-average $C_{\mathrm{OA}}$ of $\sim 5 \mu \mathrm{g} \mathrm{m}^{-3}$ is assigned to the $\log 10 C^{*} \leq-4$ bin to enable direct comparison with TD-ACSM/AMS measurements (this study and $\mathrm{Hu}$ et al., 2016). However, in reality FIGAEROCIMS observations accounted for $\sim 50 \%$ of AMS organic mass concentrations measured at Centreville (Lopez-Hilfiker et al., 2016), indicating that half the OA was not quantified. The discrepancy between FIGAERO- and TD-based distributions would be reduced if this unmeasured OA was distributed in higher-volatility bins, thus reassigning material shown in the lowest-volatility bin in Fig. 4b. Lopez-Hilfiker et al. (2016) reported that heating OA at higher temperatures has the potential to introduce artifacts into quantification of its volatility, for example if it causes oligomer decomposition leading to artificially high volatility. If this occurs, this may bias any heating-based measurement approaches, including TD measurements.

A test for these various parameter values is to use them to recreate data from other (non-heating-based) perturbations of gas-particle partitioning. Figure 5 shows evaporation kinetics of OA upon continuous stripping of vapors under isothermal $\left(25^{\circ} \mathrm{C}\right)$ conditions simulated using volatility parameter values from multiple independent approaches. The simulation framework used here is described elsewhere (Saha and Grieshop, 2016). The shaded region in Fig. 5 shows the prediction range applying dual-TD-derived parameter values from this study within estimated uncertainty ranges (campaign average and unified fits of $f_{i}, \gamma_{\mathrm{e}}=0.1$ to 1 ) with initial $C_{\mathrm{OA}}$ values from 2 to $10 \mu \mathrm{g} \mathrm{m}^{-3}$ and $d_{\mathrm{p}}=100$ and $150 \mathrm{~nm}$. Simulations are also shown with the OA volatility distribution from $\mathrm{Hu}$ et al. (2016) and FIGAERO-CIMS-derived OA volatility distribution (Lopez-Hilfiker et al., 2016) from Centreville measurements. The room temperature evaporation data from Vaden et al. (2011) measurements of ambient aerosols during the Carbonaceous Aerosols and Radiative Effects Study (CARES-2010) field campaign in Sacramento, California, are also shown. This study attributed the observed slower-than-expected evaporation to extreme kinetic limitations to mass transfer $\left(\gamma_{\mathrm{e}} \ll 0.1\right)$. Although a direct comparison of observations collected in California and simulations based on volatility distributions from Centreville is not ideal, the consistency of volatility behavior across our and other sites (Fig. 2, Table 1) suggests it is reasonable. Figure 5 shows that these data fall within the range of values simulated using our TD-estimated volatility parameter values $\left(\gamma_{\mathrm{e}} \geq 0.1\right)$. The $\mathrm{Hu}$ et al. (2016) volatility distribution with $\gamma_{\mathrm{e}}=1$ also recreates these data. In contrast, simulations with the FIGAERO-CIMS-derived OA volatility distribution (Lopez-Hilfiker et al., 2016) from Centreville measurements (assuming $\gamma_{\mathrm{e}}=1$ ) predict almost zero evaporation (dashed black line in Fig. 5). This distribution thus appears to be in-

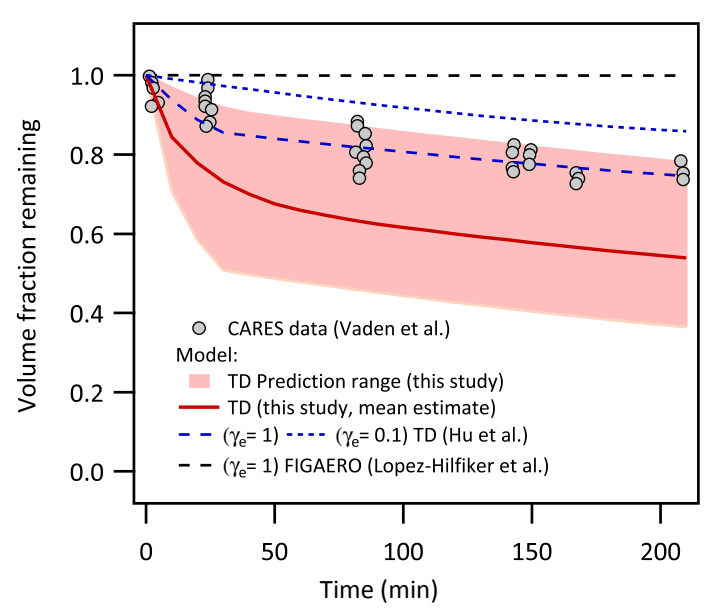

Figure 5. Isothermal evaporation kinetics of $\mathrm{OA}$ at $25^{\circ} \mathrm{C}$ (room temperature) upon continuous stripping of vapors. Shaded region shows the evaporation kinetic model prediction range applying TDderived volatility parameter values from this study; solid line shows the mean estimate. Dashed lines show model predictions using the OA volatility distribution derived using alternative approaches during the Centreville campaign (Hu et al., 2016; Lopez-Hilfiker et al., 2016). Symbols show experimental data from Vaden et al. (2011) collected during the CARES-2010 field campaign in California.

consistent with our observations and those from room temperature evaporation experiments.

\subsection{Temporal variation of $\mathrm{OA}$ volatility}

A time series of OA volatility distributions extracted over the campaign period is shown in Figs. 6 (Centreville) and S10 (Raleigh). The volatility distributions $\left(f_{i}\right)$ were extracted as described above from $\sim 6 \mathrm{~h}$ windows with fixed $\Delta H_{\text {vap }}=$ $100 \mathrm{~kJ} \mathrm{~mol}^{-1}$ and $\gamma_{\mathrm{e}}=0.5$ based on the best estimates from campaign-average fits. The average and $95 \%$ confidence intervals of $\overline{C^{*}}\left(\mu \mathrm{g} \mathrm{m}^{-3}\right)$ are $0.18(0.05-0.54)$ and $0.16(0.04-$ 0.43 ) for the Centreville and Raleigh datasets, respectively, in line with values from the campaign-average and unified fits. The OA volatility distributions do not vary dramatically over the campaign period for either site.

Ambient OA concentrations $\left(C_{\mathrm{OA}}\right)$ are shown in Fig. 6a (Centreville) and S10a (Raleigh). Figure $6 \mathrm{~b}$ shows a time series of the fractional contribution of isoprene-derived $\mathrm{OA}$ and more-oxidized oxygenated OA (MO-OOA) (Xu et al., 2015a, b) to total OA during the Centreville campaign. In a few low$C_{\mathrm{OA}}$ instances, $\overline{C^{*}}$ was found to be higher, but there was no strong relation between these two quantities (see Fig. S12, scatter plot of mean $C^{*}$ vs $C_{\mathrm{OA}}$ ). The relative contribution of MO-OOA to $C_{\mathrm{OA}}$ in many of these higher- $\bar{C}^{*}$ instances was low, likely leading to more-volatile aerosol during these periods. Isoprene was the dominant biogenic VOC ( $>80 \%$ of total VOC mass) measured during the Centreville campaign (Xu et al., 2015b) and is the biogenic VOC with greatest global emissions (Sindelarova et al., 2014). Isoprene-derived 


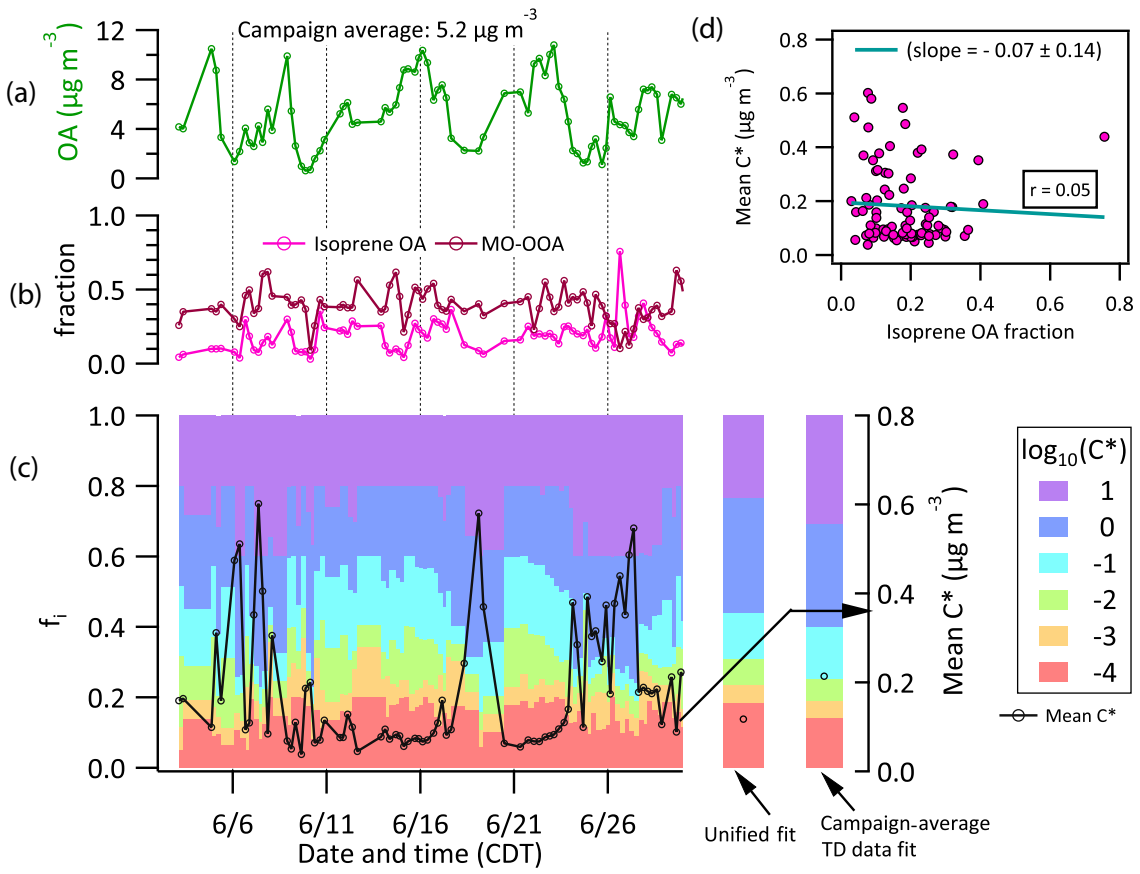

Figure 6. Time series of (a) ambient organic aerosol concentrations, $C_{\mathrm{OA}}$; (b) fractional contribution of isoprene OA and more-oxidized oxygenated OA (MO-OOA) to total OA determined from PMF analysis; and (c) OA volatility distribution $\left(f_{i}\right)$ and mean $C^{*}$ (open black circles) during the Centreville campaign. All data are averaged over $\sim 6 \mathrm{~h}$ (the time resolution of $f_{i}$ distribution). Panel (d) shows a scatter plot of mean $C^{*}$ versus isoprene-OA fraction in $C_{\mathrm{OA}}$. Figure $\mathrm{S} 10$ shows similar analysis results for the Raleigh dataset.

OA contributed $\sim 17-18 \%$ to the campaign-average $C_{\mathrm{OA}}$ at the Centreville site during the SOAS (Hu et al., 2015; Xu et al., 2015a, b), while MO-OOA contributed $\sim 39 \%$ (Xu et al., 2015a, b). Lopez-Hilfiker et al. (2016) reported that isoprene-derived $\mathrm{OA}$ was more volatile than the remaining OA using FIGAERO-CIMS measurements at the Centreville site. This result contradicts $\mathrm{Hu}$ et al. (2016), who reported a lower volatility of isoprene-derived OA than the bulk OA using TD measurements at the same site. Since our derived volatility distributions are for the bulk OA, we cannot make a specific comment on the volatility of isoprene-derived OA. However, if the volatility of isoprene-derived OA differs substantially from the remaining bulk, OA volatility might be expected to covary with the fractional contribution of isoprene$\mathrm{OA}$ to $C_{\mathrm{OA}}$. Figure $6 \mathrm{c}$ shows extracted bulk-OA volatility distributions and their mean $C^{*}$ over the Centreville campaign period. Figure $6 \mathrm{~d}$ shows a scatter plot of mean $C^{*}$ vs. the fractional contribution of isoprene-OA to $C_{\mathrm{OA}}$; the two show no correlation. Neither were statistically significant relationships found between the isoprene-OA fraction and $f_{i}$ in any particular $C^{*}$ bin (see Table S2). These results indicate that the effective volatility of isoprene OA may not be substantially different than the remaining bulk OA. If there is a difference, we are not able to detect it in our fits, potentially due to covarying contributions from other OA components.

Diurnal trends in OA volatility distributions are shown in Figs. 7 (Centreville) and S11 (Raleigh). Results show that
OA appeared less volatile in the afternoon than early in the morning for both sites (Centreville: campaign-average $\overline{C^{*}}\left(\mu \mathrm{g} \mathrm{m}^{-3}\right)$ in the morning $\sim 0.25$, afternoon $\sim 0.13$ and Raleigh: morning $\sim 0.2$, afternoon $\sim 0.12$ ). This trend is consistent with previous field measurements in Mexico City (MILAGRO) and Riverside (SOAR-1) (Huffman et al., 2009). Figure 7a shows diurnal trends of OA factors derived from PMF analysis during the Centreville campaign (Xu et al., 2015a, b). Less-oxidized oxygenated OA (LO-OOA, average $\mathrm{O}: \mathrm{C} \sim 0.63)$ dominated in the early morning $(\sim 40$ $50 \%$ ), while more-oxidized oxygenated OA (MO-OOA, average $\mathrm{O}: \mathrm{C} \sim 1.02$ ) was the largest $\mathrm{OA}$ component in the afternoon $(\sim 50 \%)$. Xu et al. (2015a) hypothesized that oxidation of monoterpenes forms a large portion of observed LO-OOA in the southeastern US via $\mathrm{NO}_{x}$ and $\mathrm{O}_{3}\left(\mathrm{NO}_{3} \mathrm{rad}-\right.$ ical) pathways, and that organo-nitrates contribute substantially to LO-OOA (20-30\%). Laboratory chamber experiments also suggest that nitrate-containing species make a significant contribution to SOA formed during terpene photooxidation and/or ozonolysis under high- $\mathrm{NO}_{x}$ conditions $(\mathrm{Ng}$ et al., 2007; Presto et al., 2005) and from reactions with nitrate radicals (Boyd et al., 2015). Lee et al. (2011) observed greater evaporation in a TD of $\alpha$-pinene and $\beta$-pinene ozonolysis SOA formed under high- $\mathrm{NO}_{x}$ conditions than under low- $\mathrm{NO}_{x}$ conditions. Thus, the higher volatility observed in the morning can likely be linked with the prevalence of LO-OOA and possible contributions from organo-nitrates. In 

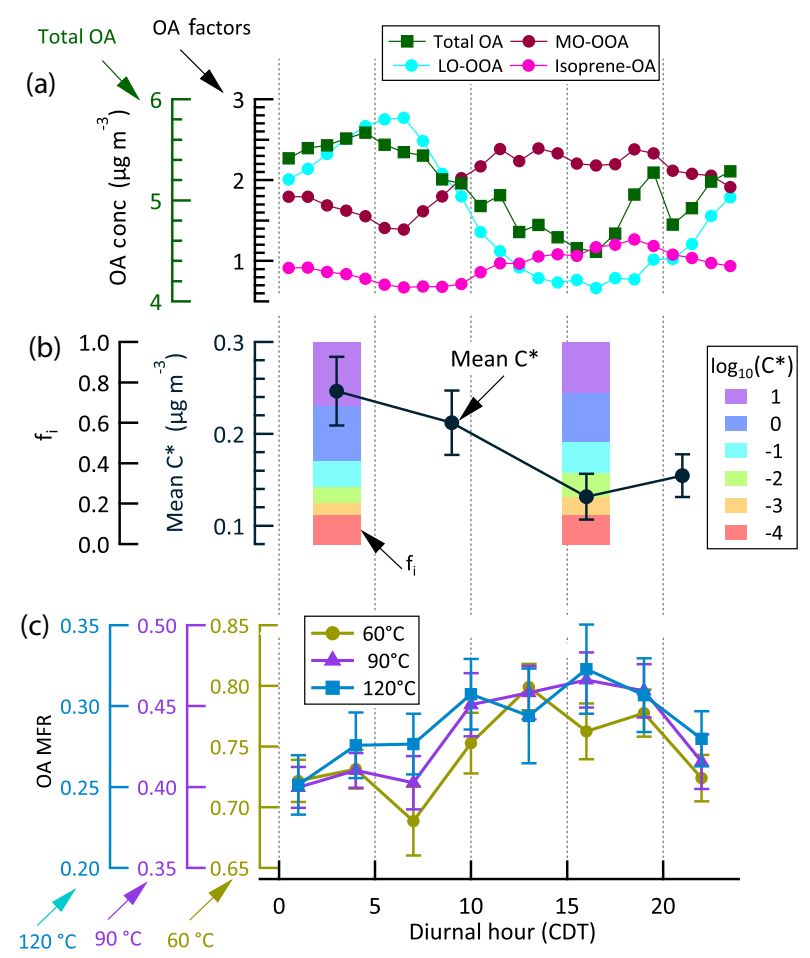

Figure 7. Campaign-average diurnal trends for the Centreville measurements of (a) concentrations of total OA and OA factors, (b) OA volatility $\left(f_{i}\right.$ and mean $\left.C^{*}\right)$, and (c) OA MFR after heating at 60,90 , and $120^{\circ} \mathrm{C}$ with a TD residence time of 50 s. Figure S11 shows similar analysis results for the Raleigh dataset. PMF factors in panel (a) are LO-OOA: less-oxidized oxygenated OA; MO-OOA: more-oxidized oxygenated OA; and isoprene-OA: isoprene-derived OA (for details on OA factors analysis see Xu et al., 2015a, b).

contrast, bulk OA was dominated by MO-OOA in the afternoon. That $\mathrm{OA}$ is relatively less volatile in the afternoon is consistent with the observation that OA volatility often decreases with increased oxidation (during functionalization) (Jimenez et al., 2009). Figure 8 shows scatter plots of $\overline{C^{*}}$ vs. LO-OOA and MO-OOA fractions of OA during the Centreville campaign. Although the average slopes of the scatter plots show an increase (decrease) of $\bar{C}^{*}$ with increasing LOOOA (MO-OOA) fraction these correlations are not strong (correlation coefficient, $r \sim 0.5$ ). Similar levels of correlation were found with effective $C^{*}$ (Fig. S13). A poor correlation between $\overline{C^{*}}$ and OA factors is also observed in the Raleigh dataset. For example, Fig. S14 shows scatter plots of $\overline{C^{*}}$ vs. tracer $(m / z)$-based HOA fraction and OOA fraction estimates ( $\mathrm{Ng}$ et al., 2011b) with an average slope of $-0.3 \pm 0.16(r \sim 0.2)$ for HOA and $-0.12 \pm 0.11(r \sim 0.1)$ for OOA.

\subsection{Average volatility and oxidation state of $\mathrm{OA}$}

Figure 9 explores the link between average carbon oxidation state, $\overline{\mathrm{OS}_{\mathrm{c}}}$, calculated as $2 \times \mathrm{O}: \mathrm{C}-\mathrm{H}: \mathrm{C}$ (Kroll et al., 2011), and $\overline{C^{*}}$. O:C and $\mathrm{H}: \mathrm{C}$ are estimated from an empirical parameterization of the $\mathrm{OA}$ elemental ratio from unit mass resolution data, given by Canagaratna et al. (2015) as a function of $f_{44}\left(\mathrm{O}: \mathrm{C}=0.079+4.31 \times f_{44}\right)$ and $f_{43}$ $\left(\mathrm{H}: \mathrm{C}=1.12+6.74 \times f_{43}-17.77 \times f_{43}^{2}\right)$, respectively. $f_{44}$ and $f_{43}$ are the fractional ion intensity at $\mathrm{m} / z$ 44 and 43 , respectively, taken from ACSM measurements. The estimated OA elemental ratios using the empirical parameterizations above are in relatively good agreement with those determined via elemental analysis of the high-resolution mass spectra data (HRToF-AMS) collected by other groups during SOAS. For example, our estimated campaign-average O : C during the Centreville campaign $(0.68 \pm 0.07)$ is within $1-2$ standard deviations of that determined in Xu et al. (2015b) $(\sim 0.78)$.

The scatter plot of $\overline{\mathrm{OS}_{\mathrm{c}}}$ vs. $\overline{C^{*}}$ (Fig. 9) shows a mild downward trend, which suggests that lower-volatility OA is associated with higher oxidation state. However, the correlation is not statistically robust $(r<0.3)$. This is consistent with the observations of $\mathrm{Xu}$ et al. (2016) and Paciga et al. (2016) who reported weak association between average oxidation state and volatility for OA measured in the London and Paris areas, respectively. The campaign-average $\overline{\mathrm{OS}_{\mathrm{c}}}$ during the Centreville measurements $(-0.18 \pm 0.15)$ was higher than in Raleigh $(-0.42 \pm 0.16)$ ( $p$ value $\ll 0.0001$ ), whereas campaign-average $\overline{C^{*}}$ values were essentially identical (Centreville: $0.18 \pm 0.14$, Raleigh: $0.16 \pm 0.12 \mu \mathrm{g} \mathrm{m}^{-3}$; $p$ value $>0.1)$.

\subsection{Application of measured volatility distribution to evaluate simulated OA in a CTM}

Figure 10 compares the measured and simulated OA volatility distributions at Centreville for June 2013. The simulated OA volatility distribution in the $C^{*}$ bins between $10^{0}$ and $10^{1} \mu \mathrm{g} \mathrm{m}^{-3}$ agrees reasonably well with observations. The model predicts a dominance of BSOA in the two bins, consistent with observations in the Centreville region. However, large discrepancies exist between the observed and simulated OA volatility distribution in the $C^{*}$ bins between $10^{-2}$ and $10^{-1} \mu \mathrm{g} \mathrm{m}^{-3}$. The model tends to greatly underpredict the $\mathrm{OA}$ concentrations in this volatility range. WRF/Chem did not reproduce the observed portion of the mass of $\mathrm{OA}$ in the lower $C^{*}$ bins, from $10^{-4}$ to $10^{-1} \mu \mathrm{g} \mathrm{m}^{-3}$, because the VBS SOA module in this version of WRF/Chem does not treat volatility in this range. Consistent with the measurement results from this study, a number of laboratory (Ehn et al., 2014; Jokinen et al., 2015; Kokkola et al., 2014; Zhang et al., 2015) and field (Hu et al., 2016; Lopez-Hilfiker et al., 2016) studies have reported that a significant fraction of SOA from biogenic precursors is low-volatility. These low- 

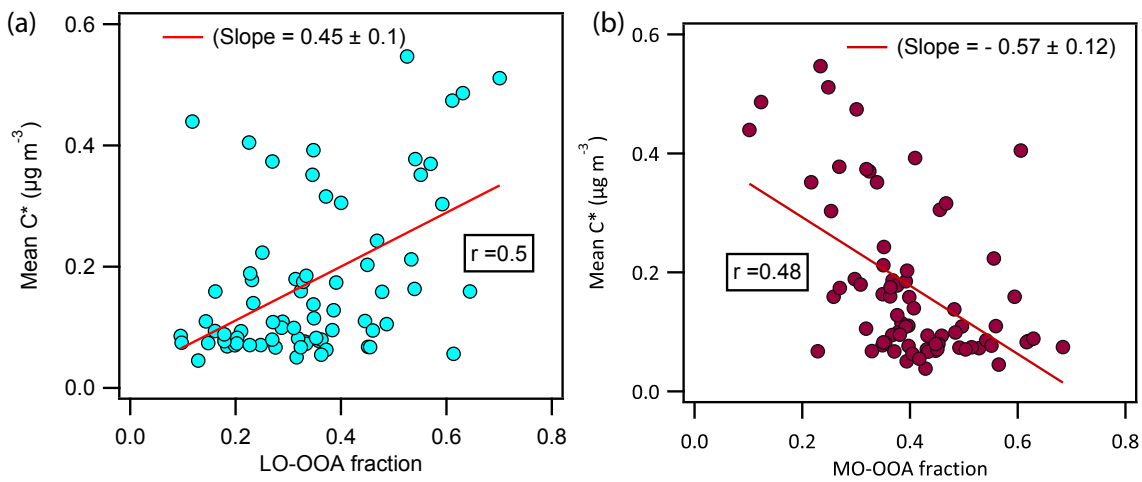

Figure 8. Scatter plot of mean $C^{*}$ versus (a) LO-OOA fraction, and (b) MO-OOA fraction in total OA concentration during the Centreville campaign.

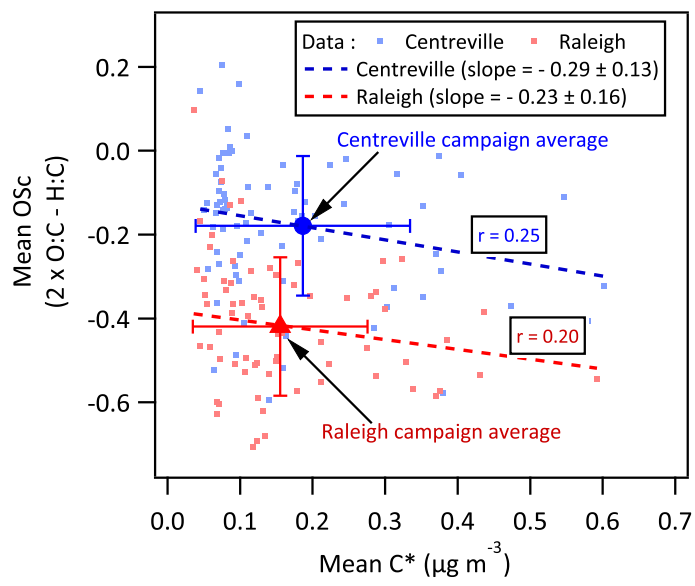

Figure 9. Mean oxidation state $\left(\overline{\mathrm{OS}_{\mathrm{c}}}\right)$ vs. mean volatility $\left(\overline{C^{*}}\right)$ measured during the Centreville and Raleigh campaigns. Dots are campaign data, dashed lines are linear regression fits of data, and symbols are the campaign average with error bar showing \pm 1 standard deviation.

volatility materials are missing in the $\mathrm{WRF} / \mathrm{Chem}$ simulation.

The simulated total OA mass concentration $\left(C_{\mathrm{OA}}\right)$ was underpredicted by a factor of 2 to 3 at Centreville during the SOAS period. Several factors may contribute to this underprediction. Comparison of WRF/Chem predictions of most relevant meteorological variables and major precursor VOCs with measurements collected during the SOAS shows a relatively good agreement. For example, the mean biases for simulated temperature at $2 \mathrm{~m}$, relative humidity at $2 \mathrm{~m}$, and wind speed at $10 \mathrm{~m}$ are $-0.9^{\circ} \mathrm{C},-0.8 \%$, and $0.3 \mathrm{~m} \mathrm{~s}^{-1}$, respectively. The normalized mean bias (NMB) of the simulated planetary boundary layer height (PBLH) is $-38 \%$, which would tend to bias OA concentrations high, suggesting that the underprediction in PBLH is not responsible for the underpredictions of OA. In terms of VOC concentrations, the model performs well for $\beta$-pinene and formaldehyde with

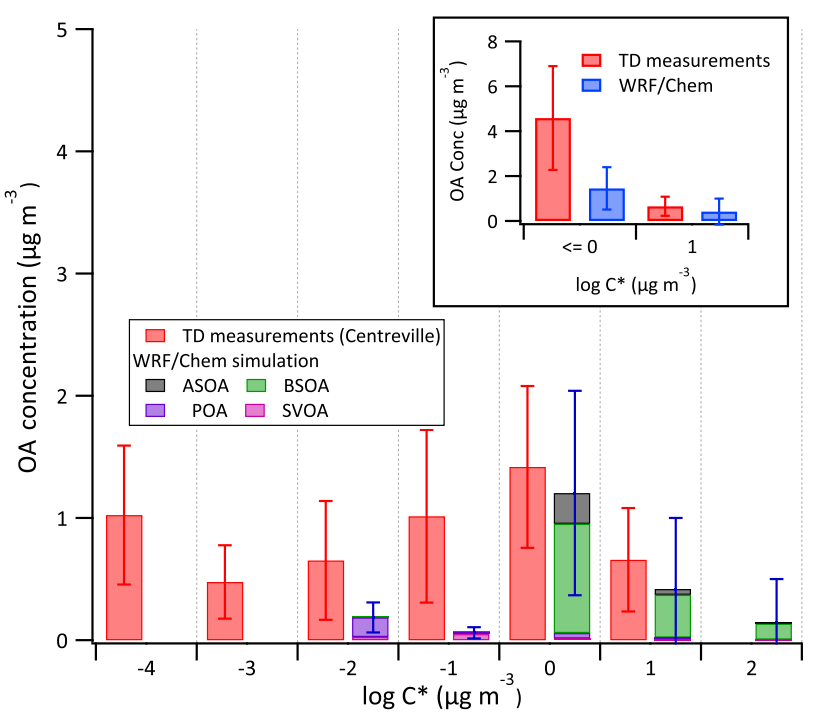

Figure 10. Comparison between measured OA volatility distributions and those simulated in WRF/Chem over the Centreville region. Bar height is mean and error bar is \pm 1 standard deviation of distributions extracted from measurements and simulations for June 2013. The inset shows a two-bin comparison (bin 1: $C^{*} \leq$ $1 \mu \mathrm{g} \mathrm{m}^{-3}$ and bin 2: $C^{*}=10 \mu \mathrm{g} \mathrm{m}^{-3}$ ). Simulated OA components include ASOA (anthropogenic-SOA), BSOA (biogenic-SOA), POA (primary-OA), and SVOA (semivolatile OA formed via oxidation of evaporated POA).

NMBs of -8.5 and $-4.3 \%$, respectively, but it underpredicts $\alpha$-pinene with an NMB of $-51.7 \%$ and significantly overpredicts limonene with an NMB of $249 \%$ (figure not shown). The WRF/Chem simulation only considers the SOA formed from a few BVOCs, including isoprene, $\alpha$-pinene, $\beta$ pinene, limonene, humulene, and ocimene, and does not account for contributions from other BSOA precursors such as other sesquiterpenes. Therefore, underestimation of precursor VOC emissions and missing precursors may contribute to OA underprediction. Other sources of uncertainty in the VBS 
treatment in WRF/Chem include the coarse spatial resolution in the model simulation, the assumed fraction of OA added for each oxidation or aging step, the assumed fragmented and functionalized percentages of organic condensable vapors, and the uncertainties in the dry- and wet-deposition velocities of SOA and SOA precursors. These factors can also contribute to the discrepancies between the model and observed $C_{\mathrm{OA}}$ at Centreville.

One likely contributor to the model's underprediction is issues with the SOA yield parameterizations in the model. Smog chamber growth-experiment-derived mass yield coefficients (i.e., distributions of product mass yield in different volatility and/or $C^{*}$ bins) (Pathak et al., 2007) are used to model SOA in a CTM. The estimated SOA yield from a traditional smog chamber experiment could be underestimated due to wall losses of condensable vapors. For example, Zhang et al. (2014) showed up to a factor of 4 yield underestimation for toluene SOA due to this effect. The high- and low- $\mathrm{NO}_{x}$ mass yields used in WRF/Chem simulations for ASOA and BSOA are based on traditional smog chamber yield experiments taken from Lane et al.(2008a). These distributions do not consider mass yields from the $C^{*}$ bins $10^{-4}$ to $10^{-1} \mu \mathrm{g} \mathrm{m}^{-3}$, where a significant portion of the OA mass was observed. The substantial amounts of low-volatility materials are typically missing in these traditional yield-measurement-based distributions (Kolesar et al., 2015b; Saha and Grieshop, 2016). Our recent dual-TD-based effort to determine the SOA mass yield distribution for $\alpha$ pinene ozonolysis (Saha and Grieshop, 2016) indicates that products are substantially less volatile than the parameterizations used in current models (including that discussed above). This $\alpha$-pinene product distribution suggests a factor of 2 4 greater SOA yield under atmospherically relevant conditions compared to traditional distributions from smog chamber growth experiments. Updating SOA mass yield coefficient data is likely required for all known precursors and may lead to large improvements in model predictions of both $C_{\mathrm{OA}}$ and OA volatility distributions.

The WRF/Chem simulation used the semiempirical $\Delta H_{\text {vap }}$ correlation derived by Epstein et al. (2010) $\left(\Delta H_{\text {vap }}=130-\right.$ $\left.11 \log _{10} C^{*}, 298 \mathrm{~K}\right)$, which gives higher values, with a steeper $\log _{10} C^{*}$ dependence than our TD-derived values $(\sim 80$ $\left.100 \mathrm{~kJ} \mathrm{~mol}^{-1}\right)$. The difference in $\Delta H_{\mathrm{vap}}$ values used in WRF/Chem and our TD-derived values should not have a significant effect on the comparison shown in Fig. 10. This is because the modeled-measured OA volatility comparison was made at temperatures (SOAS campaign-average $T=24.7^{\circ} \mathrm{C}$, WRF/Chem-simulated campaign-average $T=$ $23.8^{\circ} \mathrm{C}$ ) very close to the VBS reference temperature $\left(25^{\circ} \mathrm{C}\right)$. Murphy et al. (2011) also reported a low sensitivity of $\Delta H_{\text {vap }}$ when predicting surface OA loading during the FAME-08 study using a 2D-VBS framework. However, the effect of $\Delta H_{\text {vap }}$ could be significant when simulating OA loading at low ambient temperatures and high altitudes.

\section{Conclusions and implications}

This paper presents results from ambient-OA volatility measurements from two sites in the southeastern US under diverse conditions. Measurement campaigns were conducted at a BVOC-dominated forested rural setting during summer and another more anthropogenically influenced, but forested urban location under cooler conditions. This study applied a dual-thermodenuder (dual-TD) setup that varied temperature and residence time in parallel. Ambient OA gas-particle partitioning parameter $\left(C^{*}, \Delta H_{\mathrm{vap}}, \gamma_{\mathrm{e}}\right)$ values were extracted by fitting observed dual-TD data using an evaporation kinetic model. The OA volatility distribution derived via inverse modeling is sensitive to $\Delta H_{\text {vap }}$ and $\gamma_{\mathrm{e}}$ values. The addition of variable residence time TD (VRT-TD) data provided tighter constraints on the extracted parameter values. A $\Delta H_{\text {vap }}$ of $\sim 100 \mathrm{~kJ} \mathrm{~mole}^{-1}$ and $\gamma_{\mathrm{e}}$ of 0.5 best explain observations collected at both sites under diverse conditions. An effective $\gamma_{\mathrm{e}}$ value of $\sim 0.1$ to 1 can explain observed evaporations within variability, while a very small $\gamma_{\mathrm{e}}$ value $\left(\gamma_{\mathrm{e}} \ll 0.1\right)$ cannot fit the observations from both TDs. The Epstein et al. (2010) $\Delta H_{\text {vap }}$ correlation, which was determined based on measured properties of a variety of known compounds, also did not reproduce the evaporation observed in this study.

While measurement campaigns were conducted under different meteorological conditions at locations with varying levels of biogenic and anthropogenic emissions, the OA volatility distributions derived are found to be very similar. A substantial amount of OA (40-70\%) at both sites was found to be of very low volatility $\left(C^{*} \leq 0.1 \mu \mathrm{g} \mathrm{m}^{-3}\right)$ and will remain predominantly in the particle phase (effectively nonvolatile) under typical atmospheric conditions. OA volatility distributions also did not vary substantially over the campaign period. Our derived OA volatility parameterizations appear to be broadly consistent with observations of room temperature evaporation (Vaden et al., 2011) during CARES2010 in California. The observed consistency in OA volatility across diverse settings is an important finding, which implies that $\mathrm{OA}$ in the atmosphere formed from a variety of sources can exhibit similar volatility properties and chemical signatures. This result also suggests that measurements of OA volatility distributions such as derived here provide good diagnostics for overall model representativeness but may not be as useful for diagnosing differences across sites and conditions.

The diurnal profile of extracted OA volatility showed that bulk OA was less volatile in the afternoon than early in the morning. This trend is consistent with the prevalence of LOOOA (less oxidized) in the morning and MO-OOA (more oxidized) in the afternoon. However, while average $\mathrm{O}: \mathrm{C}$ and/or oxidation state $\left(\overline{\mathrm{OS}_{\mathrm{c}}}\right)$ of bulk OA is often considered linked to volatility, in our datasets correlations between mean oxidation state $\left(\overline{\mathrm{OS}_{\mathrm{c}}}\right)$ and mean volatility $\left(\overline{C^{*}}\right)$ were weak $(r<0.3)$. This observed weak correlation and the fact that at- 
mospheric OA is a complex mixture of organics with a broad range of volatilities and oxidation states reinforces the need to measure and understand the distribution of both volatility and oxidation states. The two-dimensional VBS framework (Donahue et al., 2012) offers one way to constrain these parameters in atmospheric models. While determination of OA volatility distributions was the focus of this study, future efforts should also measure distributions of volatility and oxidation states comprising ambient $\mathrm{OA}$.

The gas-particle partitioning parameters $\left(C^{*}, \Delta H_{\mathrm{vap}}, \gamma_{\mathrm{e}}\right)$ extracted from these measurements have important implications for the treatment and evaluation of OA in current atmospheric models. Since a CTM incorporating the VBS framework predicts OA concentrations in each volatility $\left(\log _{10} C^{*}\right)$ bin (i.e., OA volatility distribution), comparison of simulated and measured OA volatility distribution is a useful means for model evaluation beyond only comparing total OA concentration $\left(C_{\mathrm{OA}}\right)$. Here, we compared our measured OA volatility distribution with that simulated by WRF/Chem. This evaluation indicates that $\mathrm{OA}$ volatility distributions predicted in WRF/Chem are inconsistent with measurements over the $C^{*}$ range from $10^{-4}$ to $10^{-1} \mu \mathrm{g} \mathrm{m}^{-3}$. This may give important clues towards the root causes of the model's underestimation of $C_{\mathrm{OA}}$ by a factor of 2 to 3 . In comparison to our TD-derived OA volatility distribution and other recent evidence (Ehn et al., 2014; Hu et al., 2016; Jokinen et al., 2015; Kokkola et al., 2014; Lopez-Hilfiker et al., 2016; Saha and Grieshop, 2016), low-volatility materials are mostly missing from the WRF/Chem predictions. Recent evidence of SOA from aqueous-phase oxidation in presence of abundant particle water (Carlton and Turpin, 2013; Marais et al., 2016), formation of oligomers, and large molecular compounds directly in the gas phase (Ehn et al., 2014) and via condensedphase chemistry (Kroll et al., 2015; Kroll and Seinfeld, 2008) suggest that complex and multiphase formation and evolution processes produce SOA in the atmosphere. Many of these processes can produce very-low-volatility organics and most are not included in current CTMs. These low-volatility organics appear to make significant contributions to the atmospheric OA budget and cloud condensation nuclei formation (Jokinen et al., 2015).

The $\Delta H_{\mathrm{vap}}$ and $\gamma_{\mathrm{e}}$ values extracted here for atmospheric OA in the southeastern US also have important implications for predicting OA concentrations in a CTM. First, a $\Delta H_{\text {vap }}$ value of $30-40 \mathrm{~kJ} \mathrm{~mol}^{-1}$ (Farina et al., 2010; Lane et al., 2008b; Pye and Seinfeld, 2010) is typically assumed for modeling OA in a CTM, which is substantially lower than that suggested by our TD observations $\left(\sim 100 \mathrm{~kJ} \mathrm{~mol}^{-1}\right)$. An increase of assumed $\Delta H_{\text {vap }}$ value can increase atmospheric OA burden and lifetime for a particular input volatility distribution (Farina et al., 2010), especially at low ambient temperatures and high altitudes. Finally, a value of $\gamma_{\mathrm{e}} \geq 0.1$ indicates a gas-particle repartitioning timescale (Saleh et al., 2013) on the order of minutes to an hour under atmospherically relevant conditions $\left(N_{\mathrm{p}} \sim 1000-5000 \mathrm{~cm}^{-3}\right)$. There- fore, the equilibrium phase-partitioning assumption typically made in CTMs should be reasonable for a prediction timestep of $\sim 1 \mathrm{~h}$.

\section{Data availability}

Some of the data used in this study are publicly available at https://data.eol.ucar.edu/dataset/373.049 (Grieshop et al., 2017). Other data can be obtained from the authors upon request (apgriesh@ncsu.edu).

\section{The Supplement related to this article is available online at doi:10.5194/acp-17-501-2017-supplement.}

Acknowledgements. We thank Satoshi Takahama and his research group at EPFL for their help and support during the SOAS campaign, Paul Shepson's group (Purdue University) for BVOC data, SEARCH Network for temperature, relative humidity, mixing height, $\mathrm{CO}$, and $\mathrm{NO}_{x}$ data from the Centreville site. Operation of the SEARCH network and analysis of its data collection are sponsored by the Southern Co. and Electric Power Research Institute.

Funding was provided by start-up support from North Carolina State University, Raleigh, US. Andrey Khlystov acknowledges funding by the US EPA (grant 83541101). Contents of this publication are solely the responsibility of the authors and do not necessarily represent the official views of the US EPA. Furthermore, the US EPA does not endorse the purchase of any commercial products or services mentioned in the publication. Khairunnisa Yahya and Yang Zhang acknowledge funding from the National Science Foundation EaSM program (AGS-1049200) for WRF/Chem simulations and high-performance computing support from Stampede, provided as an Extreme Science and Engineering Discovery Environment (XSEDE) digital service by the Texas Advanced Computing Center (TACC) (http://www.tacc.utexas.edu), which is supported by National Science Foundation grant number ACI-1053575 and Yellowstone (ark:/85065/d7wd3xhc) provided by NCAR's Computational and Information Systems Laboratory, sponsored by the National Science Foundation and Information Systems Laboratory. Lu Xu and Nga L. Ng acknowledge National Science Foundation grant 1242258 and US Environmental Protection Agency STAR grant RD-83540301.

Edited by: B. Ervens

Reviewed by: two anonymous referees

\section{References}

Ackermann, I. J., Hass, H., Memmesheimer, M., Ebel, A., Binkowski, F. S., and Shankar, U.: Modal aerosol dynamics model for Europe: development and first applications, Atmos. Environ., 32, 2981-2999, doi:10.1016/S1352-2310(98)00006-5, 1998. 
Ahmadov, R., McKeen, S. A., Robinson, A. L., Bahreini, R., Middlebrook, A. M., de Gouw, J. A., Meagher, J., Hsie, E.-Y., Edgerton, E., Shaw, S., and Trainer, M.: A volatility basis set model for summertime secondary organic aerosols over the eastern United States in 2006, J. Geophys. Res.-Atmos., 117, D06301, doi:10.1029/2011JD016831, 2012.

Bilde, M., Barsanti, K., Booth, M., Cappa, C. D., Donahue, N. M., Emanuelsson, E. U., McFiggans, G., Krieger, U. K., Marcolli, C., Topping, D., Ziemann, P., Barley, M., Clegg, S., Dennis-Smither, B., Hallquist, M., Hallquist, Å. M., Khlystov, A., Kulmala, M., Mogensen, D., Percival, C. J., Pope, F., Reid, J. P., Ribeiro da Silva, M. A. V., Rosenoern, T., Salo, K., Soonsin, V. P., Yli-Juuti, T., Prisle, N. L., Pagels, J., Rarey, J., Zardini, A. A., and Riipinen, I.: Saturation Vapor Pressures and Transition Enthalpies of Low-Volatility Organic Molecules of Atmospheric Relevance: From Dicarboxylic Acids to Complex Mixtures, Chem. Rev., 115, 4115-4156, doi:10.1021/cr5005502, 2015.

Boyd, C. M., Sanchez, J., Xu, L., Eugene, A. J., Nah, T., Tuet, W. Y., Guzman, M. I., and Ng, N. L.: Secondary organic aerosol formation from the $\beta$-pinene $+\mathrm{NO}_{3}$ system: effect of humidity and peroxy radical fate, Atmos. Chem. Phys., 15, 7497-7522, doi:10.5194/acp-15-7497-2015, 2015.

Budisulistiorini, S. H., Li, X., Bairai, S. T., Renfro, J., Liu, Y., Liu, Y. J., McKinney, K. A., Martin, S. T., McNeill, V. F., Pye, H. O. T., Nenes, A., Neff, M. E., Stone, E. A., Mueller, S., Knote, C., Shaw, S. L., Zhang, Z., Gold, A., and Surratt, J. D.: Examining the effects of anthropogenic emissions on isoprenederived secondary organic aerosol formation during the 2013 Southern Oxidant and Aerosol Study (SOAS) at the Look Rock, Tennessee ground site, Atmos. Chem. Phys., 15, 8871-8888, doi:10.5194/acp-15-8871-2015, 2015.

Burtscher, H., Baltensperger, U., Bukowiecki, N., Cohn, P., Hüglin, C., Mohr, M., Matter, U., Nyeki, S., Schmatloch, V., Streit, N., and Weingartner, E.: Separation of volatile and nonvolatile aerosol fractions by thermodesorption: instrumental development and applications, J. Aerosol Sci., 32, 427-442, doi:10.1016/S0021-8502(00)00089-6, 2001.

Canagaratna, M. R., Jimenez, J. L., Kroll, J. H., Chen, Q., Kessler, S. H., Massoli, P., Hildebrandt Ruiz, L., Fortner, E., Williams, L. R., Wilson, K. R., Surratt, J. D., Donahue, N. M., Jayne, J. T., and Worsnop, D. R.: Elemental ratio measurements of organic compounds using aerosol mass spectrometry: characterization, improved calibration, and implications, Atmos. Chem. Phys., 15, 253-272, doi:10.5194/acp-15-253-2015, 2015.

Cappa, C. D.: A model of aerosol evaporation kinetics in a thermodenuder, Atmos. Meas. Tech., 3, 579-592, doi:10.5194/amt3-579-2010, 2010.

Cappa, C. D. and Jimenez, J. L.: Quantitative estimates of the volatility of ambient organic aerosol, Atmos. Chem. Phys., 10, 5409-5424, doi:10.5194/acp-10-5409-2010, 2010.

Carlton, A. G. and Turpin, B. J.: Particle partitioning potential of organic compounds is highest in the Eastern US and driven by anthropogenic water, Atmos. Chem. Phys., 13, 10203-10214, doi:10.5194/acp-13-10203-2013, 2013.

Cerully, K. M., Bougiatioti, A., Hite Jr., J. R., Guo, H., Xu, L., Ng, N. L., Weber, R., and Nenes, A.: On the link between hygroscopicity, volatility, and oxidation state of ambient and water-soluble aerosols in the southeastern United States, Atmos. Chem. Phys., 15, 8679-8694, doi:10.5194/acp-15-8679-2015, 2015.
Donahue, N. M., Robinson, A. L., Stanier, C. O., and Pandis, S. N.: Coupled Partitioning, Dilution, and Chemical Aging of Semivolatile Organics, Environ. Sci. Technol., 40, 2635-2643, doi:10.1021/es052297c, 2006.

Donahue, N. M., Kroll, J. H., Pandis, S. N., and Robinson, A. L.: A two-dimensional volatility basis set - Part 2: Diagnostics of organic-aerosol evolution, Atmos. Chem. Phys., 12, 615-634, doi:10.5194/acp-12-615-2012, 2012.

Ehn, M., Thornton, J. A., Kleist, E., Sipilä, M., Junninen, H., Pullinen, I., Springer, M., Rubach, F., Tillmann, R., Lee, B., LopezHilfiker, F., Andres, S., Acir, I.-H., Rissanen, M., Jokinen, T., Schobesberger, S., Kangasluoma, J., Kontkanen, J., Nieminen, T., Kurtén, T., Nielsen, L. B., Jørgensen, S., Kjaergaard, H. G., Canagaratna, M., Maso, M. D., Berndt, T., Petäjä, T., Wahner, A., Kerminen, V.-M., Kulmala, M., Worsnop, D. R., Wildt, J., and Mentel, T. F.: A large source of low-volatility secondary organic aerosol, Nature, 506, 476-479, doi:10.1038/nature13032, 2014.

El-Sayed, M. M. H., Amenumey, D., and Hennigan, C. J.: Drying-Induced Evaporation of Secondary Organic Aerosol during Summer, Environ. Sci. Technol., 50, 3626-3633, doi:10.1021/acs.est.5b06002, 2016.

Epstein, S. A., Riipinen, I., and Donahue, N. M.: A Semiempirical Correlation between Enthalpy of Vaporization and Saturation Concentration for Organic Aerosol, Environ. Sci. Technol., 44, 743-748, doi:10.1021/es902497z, 2010.

Farina, S. C., Adams, P. J., and Pandis, S. N.: Modeling global secondary organic aerosol formation and processing with the volatility basis set: Implications for anthropogenic secondary organic aerosol, J. Geophys. Res.-Atmos., 115, D09202, doi:10.1029/2009JD013046, 2010.

Faulhaber, A. E., Thomas, B. M., Jimenez, J. L., Jayne, J. T., Worsnop, D. R., and Ziemann, P. J.: Characterization of a thermodenuder-particle beam mass spectrometer system for the study of organic aerosol volatility and composition, Atmos. Meas. Tech., 2, 15-31, doi:10.5194/amt-2-15-2009, 2009.

Gantt, B., He, J., Zhang, X., Zhang, Y., and Nenes, A.: Incorporation of advanced aerosol activation treatments into CESM/CAM5: model evaluation and impacts on aerosol indirect effects, Atmos. Chem. Phys., 14, 7485-7497, doi:10.5194/acp-14-74852014, 2014.

Goldstein, A. H. and Galbally, I. E.: Known and Unexplored Organic Constituents in the Earth's Atmosphere, Environ. Sci. Technol., 41, 1514-1521, doi:10.1021/es072476p, 2007.

Goldstein, A. H., Koven, C. D., Heald, C. L., and Fung, I. Y.: Biogenic carbon and anthropogenic pollutants combine to form a cooling haze over the southeastern United States, P. Natl. Acad. Sci., 106, 8835-8840, doi:10.1073/pnas.0904128106, 2009.

Grieshop, A. P., Donahue, N. M., and Robinson, A. L.: Is the gas-particle partitioning in alpha-pinene secondary organic aerosol reversible?, Geophys. Res. Lett., 34, L14810, doi:10.1029/2007GL029987, 2007.

Grieshop, A. P., Miracolo, M. A., Donahue, N. M., and Robinson, A. L.: Constraining the Volatility Distribution and Gas-Particle Partitioning of Combustion Aerosols Using Isothermal Dilution and Thermodenuder Measurements, Environ. Sci. Technol., 43, 4750-4756, doi:10.1021/es8032378, 2009. 
Grieshop, A., Saha, P., and Khlystov, A.: Ambient OA Volatility Measurements during the SOAS, Version 1.0, UCAR/NCAR Earth Observing Laboratory, doi:10.5065/D61J9848, 2017.

Guenther, A. B., Jiang, X., Heald, C. L., Sakulyanontvittaya, T., Duhl, T., Emmons, L. K., and Wang, X.: The Model of Emissions of Gases and Aerosols from Nature version 2.1 (MEGAN2.1): an extended and updated framework for modeling biogenic emissions, Geosci. Model Dev., 5, 1471-1492, doi:10.5194/gmd-51471-2012, 2012.

Häkkinen, S. A. K., Äijälä, M., Lehtipalo, K., Junninen, H., Backman, J., Virkkula, A., Nieminen, T., Vestenius, M., Hakola, H., Ehn, M., Worsnop, D. R., Kulmala, M., Petäjä, T., and Riipinen, I.: Long-term volatility measurements of submicron atmospheric aerosol in Hyytiälä, Finland, Atmos. Chem. Phys., 12, 1077110786, doi:10.5194/acp-12-10771-2012, 2012.

Hallquist, M., Wenger, J. C., Baltensperger, U., Rudich, Y., Simpson, D., Claeys, M., Dommen, J., Donahue, N. M., George, C., Goldstein, A. H., Hamilton, J. F., Herrmann, H., Hoffmann, T., Iinuma, Y., Jang, M., Jenkin, M. E., Jimenez, J. L., Kiendler-Scharr, A., Maenhaut, W., McFiggans, G., Mentel, Th. F., Monod, A., Prévôt, A. S. H., Seinfeld, J. H., Surratt, J. D., Szmigielski, R., and Wildt, J.: The formation, properties and impact of secondary organic aerosol: current and emerging issues, Atmos. Chem. Phys., 9, 5155-5236, doi:10.5194/acp-9-51552009, 2009.

He, J. and Zhang, Y.: Improvement and further development in CESM/CAM5: gas-phase chemistry and inorganic aerosol treatments, Atmos. Chem. Phys., 14, 9171-9200, doi:10.5194/acp14-9171-2014, 2014.

Hennigan, C. J., Bergin, M. H., Russell, A. G., Nenes, A., and Weber, R. J.: Gas/particle partitioning of water-soluble organic aerosol in Atlanta, Atmos. Chem. Phys., 9, 3613-3628, doi:10.5194/acp-9-3613-2009, 2009.

Hu, W., Palm, B. B., Day, D. A., Campuzano-Jost, P., Krechmer, J. E., Peng, Z., de Sá, S. S., Martin, S. T., Alexander, M. L., Baumann, K., Hacker, L., Kiendler-Scharr, A., Koss, A. R., de Gouw, J. A., Goldstein, A. H., Seco, R., Sjostedt, S. J., Park, J.-H., Guenther, A. B., Kim, S., Canonaco, F., Prévôt, A. S. H., Brune, W. H., and Jimenez, J. L.: Volatility and lifetime against $\mathrm{OH}$ heterogeneous reaction of ambient isoprene-epoxydiols-derived secondary organic aerosol (IEPOX-SOA), Atmos. Chem. Phys., 16, 11563-11580, doi:10.5194/acp-16-11563-2016, 2016.

Hu, W. W., Campuzano-Jost, P., Palm, B. B., Day, D. A., Ortega, A. M., Hayes, P. L., Krechmer, J. E., Chen, Q., Kuwata, M., Liu, Y. J., de Sá, S. S., McKinney, K., Martin, S. T., Hu, M., Budisulistiorini, S. H., Riva, M., Surratt, J. D., St. Clair, J. M., Isaacman-Van Wertz, G., Yee, L. D., Goldstein, A. H., Carbone, S., Brito, J., Artaxo, P., de Gouw, J. A., Koss, A., Wisthaler, A., Mikoviny, T., Karl, T., Kaser, L., Jud, W., Hansel, A., Docherty, K. S., Alexander, M. L., Robinson, N. H., Coe, H., Allan, J. D., Canagaratna, M. R., Paulot, F., and Jimenez, J. L.: Characterization of a real-time tracer for isoprene epoxydiols-derived secondary organic aerosol (IEPOX-SOA) from aerosol mass spectrometer measurements, Atmos. Chem. Phys., 15, 11807-11833, doi:10.5194/acp-15-11807-2015, 2015.

Huffman, J. A., Ziemann, P. J., Jayne, J. T., Worsnop, D. R., and Jimenez, J. L.: Development and Characterization of a FastStepping/Scanning Thermodenuder for Chemically-Resolved
Aerosol Volatility Measurements, Aerosol Sci. Tech., 42, 395407, doi:10.1080/02786820802104981, 2008.

Huffman, J. A., Docherty, K. S., Aiken, A. C., Cubison, M. J., Ulbrich, I. M., DeCarlo, P. F., Sueper, D., Jayne, J. T., Worsnop, D. R., Ziemann, P. J., and Jimenez, J. L.: Chemically-resolved aerosol volatility measurements from two megacity field studies, Atmos. Chem. Phys., 9, 7161-7182, doi:10.5194/acp-9-71612009, 2009.

Jimenez, J. L., Canagaratna, M. R., Donahue, N. M., Prevot, A. S. H., Zhang, Q., Kroll, J. H., DeCarlo, P. F., Allan, J. D., Coe, H., Ng, N. L., Aiken, A. C., Docherty, K. S., Ulbrich, I. M., Grieshop, A. P., Robinson, A. L., Duplissy, J., Smith, J. D., Wilson, K. R., Lanz, V. A., Hueglin, C., Sun, Y. L., Tian, J., Laaksonen, A., Raatikainen, T., Rautiainen, J., Vaattovaara, P., Ehn, M., Kulmala, M., Tomlinson, J. M., Collins, D. R., Cubison, M. J., Dunlea, J., Huffman, J. A., Onasch, T. B., Alfarra, M. R., Williams, P. I., Bower, K., Kondo, Y., Schneider, J., Drewnick, F., Borrmann, S., Weimer, S., Demerjian, K., Salcedo, D., Cottrell, L., Griffin, R., Takami, A., Miyoshi, T., Hatakeyama, S., Shimono, A., Sun, J. Y., Zhang, Y. M., Dzepina, K., Kimmel, J. R., Sueper, D., Jayne, J. T., Herndon, S. C., Trimborn, A. M., Williams, L. R., Wood, E. C., Middlebrook, A. M., Kolb, C. E., Baltensperger, U., and Worsnop, D. R.: Evolution of Organic Aerosols in the Atmosphere, Science, 326, 1525-1529, doi:10.1126/science.1180353, 2009.

Jokinen, T., Berndt, T., Makkonen, R., Kerminen, V.-M., Junninen, H., Paasonen, P., Stratmann, F., Herrmann, H., Guenther, A. B., Worsnop, D. R., Kulmala, M., Ehn, M., and Sipilä, M.: Production of extremely low volatile organic compounds from biogenic emissions: Measured yields and atmospheric implications, P. Natl. Acad. Sci., 112, 7123-7128, doi:10.1073/pnas.1423977112, 2015.

Kokkola, H., Yli-Pirilä, P., Vesterinen, M., Korhonen, H., Keskinen, H., Romakkaniemi, S., Hao, L., Kortelainen, A., Joutsensaari, J., Worsnop, D. R., Virtanen, A., and Lehtinen, K. E. J.: The role of low volatile organics on secondary organic aerosol formation, Atmos. Chem. Phys., 14, 1689-1700, doi:10.5194/acp-14-16892014, 2014.

Kolesar, K. R., Li, Z., Wilson, K. R., and Cappa, C. D.: Heating-Induced Evaporation of Nine Different Secondary Organic Aerosol Types, Environ. Sci. Technol., 49, 12242-12252, doi:10.1021/acs.est.5b03038, 2015a.

Kolesar, K. R., Chen, C., Johnson, D., and Cappa, C. D.: The influences of mass loading and rapid dilution of secondary organic aerosol on particle volatility, Atmos. Chem. Phys., 15, 9327 9343, doi:10.5194/acp-15-9327-2015, 2015b.

Kroll, J. H. and Seinfeld, J. H.: Chemistry of secondary organic aerosol: Formation and evolution of low-volatility organics in the atmosphere, Atmos. Environ., 42, 3593-3624, doi:10.1016/j.atmosenv.2008.01.003, 2008.

Kroll, J. H., Donahue, N. M., Jimenez, J. L., Kessler, S. H., Canagaratna, M. R., Wilson, K. R., Altieri, K. E., Mazzoleni, L. R., Wozniak, A. S., Bluhm, H., Mysak, E. R., Smith, J. D., Kolb, C. E., and Worsnop, D. R.: Carbon oxidation state as a metric for describing the chemistry of atmospheric organic aerosol, Nat. Chem., 3, 133-139, doi:10.1038/nchem.948, 2011.

Kroll, J. H., Lim, C. Y., Kessler, S. H., and Wilson, K. R.: Heterogeneous Oxidation of Atmospheric Organic Aerosol: Kinetics of Changes to the Amount and Oxidation State of Particle- 
Phase Organic Carbon, J. Phys. Chem. A, 119, 10767-10783, doi:10.1021/acs.jpca.5b06946, 2015.

Lane, T. E., Donahue, N. M., and Pandis, S. N.: Effect of $\mathrm{NO}_{x}$ on Secondary Organic Aerosol Concentrations, Environ. Sci. Technol., 42, 6022-6027, doi:10.1021/es703225a, 2008a.

Lane, T. E., Donahue, N. M., and Pandis, S. N.: Simulating secondary organic aerosol formation using the volatility basis-set approach in a chemical transport model, Atmos. Environ., 42, 7439-7451, doi:10.1016/j.atmosenv.2008.06.026, 2008b.

Lappalainen, H. K., Sevanto, S., Bäck, J., Ruuskanen, T. M., Kolari, P., Taipale, R., Rinne, J., Kulmala, M., and Hari, P.: Daytime concentrations of biogenic volatile organic compounds in a boreal forest canopy and their relation to environmental and biological factors, Atmos. Chem. Phys., 9, 5447-5459, doi:10.5194/acp-9-5447-2009, 2009.

Lee, B. H., Kostenidou, E., Hildebrandt, L., Riipinen, I., Engelhart, G. J., Mohr, C., DeCarlo, P. F., Mihalopoulos, N., Prevot, A. S. H., Baltensperger, U., and Pandis, S. N.: Measurement of the ambient organic aerosol volatility distribution: application during the Finokalia Aerosol Measurement Experiment (FAME2008), Atmos. Chem. Phys., 10, 12149-12160, doi:10.5194/acp10-12149-2010, 2010.

Lee, B.-H., Pierce, J. R., Engelhart, G. J., and Pandis, S. N.: Volatility of secondary organic aerosol from the ozonolysis of monoterpenes, Atmos. Environ., 45, 2443-2452, doi:10.1016/j.atmosenv.2011.02.004, 2011.

Lehtinen, K., Korhonen, H., Maso, M. D., and Kulmala, M.: On the concept of condensation sink diameter, Boreal Environ. Res., 8, 405-411, 2003.

Liao, H., Henze, D. K., Seinfeld, J. H., Wu, S., and Mickley, L. J.: Biogenic secondary organic aerosol over the United States: Comparison of climatological simulations with observations, J. Geophys. Res.-Atmos., 112, D06201, doi:10.1029/2006JD007813, 2007.

Lopez-Hilfiker, F. D., Mohr, C., D’Ambro, E. L., Lutz, A., Riedel, T. P., Gaston, C. J., Iyer, S., Zhang, Z., Gold, A., Surratt, J. D., Lee, B. H., Kurten, T., Hu, W. W., Jimenez, J., Hallquist, M., and Thornton, J. A.: Molecular Composition and Volatility of Organic Aerosol in the Southeastern U.S.: Implications for IEPOX Derived SOA, Environ. Sci. Technol., 50, 2200-2209, doi:10.1021/acs.est.5b04769, 2016.

Marais, E. A., Jacob, D. J., Jimenez, J. L., Campuzano-Jost, P., Day, D. A., Hu, W., Krechmer, J., Zhu, L., Kim, P. S., Miller, C. C., Fisher, J. A., Travis, K., Yu, K., Hanisco, T. F., Wolfe, G. M., Arkinson, H. L., Pye, H. O. T., Froyd, K. D., Liao, J., and McNeill, V. F.: Aqueous-phase mechanism for secondary organic aerosol formation from isoprene: application to the southeast United States and co-benefit of $\mathrm{SO}_{2}$ emission controls, Atmos. Chem. Phys., 16, 1603-1618, doi:10.5194/acp-16-16032016, 2016.

Matsui, H., Koike, M., Kondo, Y., Takami, A., Fast, J. D., Kanaya, Y., and Takigawa, M.: Volatility basis-set approach simulation of organic aerosol formation in East Asia: implications for anthropogenic-biogenic interaction and controllable amounts, Atmos. Chem. Phys., 14, 9513-9535, doi:10.5194/acp-14-95132014, 2014.

May, A. A., Levin, E. J. T., Hennigan, C. J., Riipinen, I., Lee, T., Collett, J. L., Jimenez, J. L., Kreidenweis, S. M., and Robinson, A. L.: Gas-particle partitioning of primary organic aerosol emissions: 3. Biomass burning, J. Geophys. Res.-Atmos., 118, 11327-11338, doi:10.1002/jgrd.50828, 2013.

Murphy, B. N., Donahue, N. M., Fountoukis, C., and Pandis, S. N.: Simulating the oxygen content of ambient organic aerosol with the 2D volatility basis set, Atmos. Chem. Phys., 11, 7859-7873, doi:10.5194/acp-11-7859-2011, 2011.

Ng, N. L., Chhabra, P. S., Chan, A. W. H., Surratt, J. D., Kroll, J. H., Kwan, A. J., McCabe, D. C., Wennberg, P. O., Sorooshian, A., Murphy, S. M., Dalleska, N. F., Flagan, R. C., and Seinfeld, J. H.: Effect of $\mathrm{NO}_{x}$ level on secondary organic aerosol (SOA) formation from the photooxidation of terpenes, Atmos. Chem. Phys., 7, 5159-5174, doi:10.5194/acp-7-5159-2007, 2007.

Ng, N. L., Herndon, S. C., Trimborn, A., Canagaratna, M. R., Croteau, P. L., Onasch, T. B., Sueper, D., Worsnop, D. R., Zhang, Q., Sun, Y. L., and Jayne, J. T.: An Aerosol Chemical Speciation Monitor (ACSM) for Routine Monitoring of the Composition and Mass Concentrations of Ambient Aerosol, Aerosol Sci. Tech., 45, 780-794, doi:10.1080/02786826.2011.560211, 2011a.

Ng, N. L., Canagaratna, M. R., Jimenez, J. L., Zhang, Q., Ulbrich, I. M., and Worsnop, D. R.: Real-Time Methods for Estimating Organic Component Mass Concentrations from Aerosol Mass Spectrometer Data, Environ. Sci. Technol., 45, 910-916, doi:10.1021/es102951k, 2011b.

Offenberg, J. H., Kleindienst, T. E., Jaoui, M., Lewandowski, M., and Edney, E. O.: Thermal properties of secondary organic aerosols, Geophys. Res. Lett., 33, L03816, doi:10.1029/2005GL024623, 2006.

Paciga, A., Karnezi, E., Kostenidou, E., Hildebrandt, L., Psichoudaki, M., Engelhart, G. J., Lee, B.-H., Crippa, M., Prévôt, A. S. H., Baltensperger, U., and Pandis, S. N.: Volatility of organic aerosol and its components in the megacity of Paris, Atmos. Chem. Phys., 16, 2013-2023, doi:10.5194/acp-16-20132016, 2016.

Pankow, J. F.: An absorption model of gas/particle partitioning of organic compounds in the atmosphere, Atmos. Environ., 28, 185-188, doi:10.1016/1352-2310(94)90093-0, 1994.

Pathak, R. K., Presto, A. A., Lane, T. E., Stanier, C. O., Donahue, N. M., and Pandis, S. N.: Ozonolysis of $\alpha$-pinene: parameterization of secondary organic aerosol mass fraction, Atmos. Chem. Phys., 7, 3811-3821, doi:10.5194/acp-7-3811-2007, 2007.

Pouliot, G., Denier van der Gon, H. A. C., Kuenen, J., Zhang, J., Moran, M. D., and Makar, P. A.: Analysis of the emission inventories and model-ready emission datasets of Europe and North America for phase 2 of the AQMEII project, Atmos. Environ., 115, 345-360, doi:10.1016/j.atmosenv.2014.10.061, 2015.

Presto, A. A., Huff Hartz, K. E., and Donahue, N. M.: Secondary Organic Aerosol Production from Terpene Ozonolysis. 2. Effect of $\mathrm{NO}_{x}$ Concentration, Environ. Sci. Technol., 39, 7046-7054, doi:10.1021/es050400s, 2005.

Pye, H. O. T. and Seinfeld, J. H.: A global perspective on aerosol from low-volatility organic compounds, Atmos. Chem. Phys., 10, 4377-4401, doi:10.5194/acp-10-4377-2010, 2010.

Pye, H. O. T., Luecken, D. J., Xu, L., Boyd, C. M., Ng, N. L., Baker, K. R., Ayres, B. R., Bash, J. O., Baumann, K., Carter, W. P. L., Edgerton, E., Fry, J. L., Hutzell, W. T., Schwede, D. B., and Shepson, P. B.: Modeling the Current and Future Roles of Particulate Organic Nitrates in the Southeastern United States, Environ. Sci. Technol., 49, 14195-14203, doi:10.1021/acs.est.5b03738, 2015. 
Ranjan, M., Presto, A. A., May, A. A., and Robinson, A. L.: Temperature Dependence of Gas-Particle Partitioning of Primary Organic Aerosol Emissions from a Small Diesel Engine, Aerosol Sci. Tech., 46, 13-21, doi:10.1080/02786826.2011.602761, 2012.

Riipinen, I., Pierce, J. R., Donahue, N. M., and Pandis, S. N.: Equilibration time scales of organic aerosol inside thermodenuders: Evaporation kinetics vs. thermodynamics, Atmos. Environ., 44, 597-607, doi:10.1016/j.atmosenv.2009.11.022, 2010.

Saha, P. K. and Grieshop, A. P.: Exploring Divergent Volatility Properties from Yield and Thermodenuder Measurements of Secondary Organic Aerosol from $\alpha$-Pinene Ozonolysis, Environ. Sci. Technol., 50, 5740-5749, doi:10.1021/acs.est.6b00303, 2016.

Saha, P. K., Khlystov, A., and Grieshop, A. P.: Determining Aerosol Volatility Parameters Using a "Dual Thermodenuder" System: Application to Laboratory-Generated Organic Aerosols, Aerosol Sci. Tech., 49, 620-632, doi:10.1080/02786826.2015.1056769, 2015.

Saleh, R., Shihadeh, A., and Khlystov, A.: On transport phenomena and equilibration time scales in thermodenuders, Atmos. Meas. Tech., 4, 571-581, doi:10.5194/amt-4-571-2011, 2011.

Saleh, R., Khlystov, A., and Shihadeh, A.: Determination of Evaporation Coefficients of Ambient and Laboratory-Generated Semivolatile Organic Aerosols from Phase Equilibration Kinetics in a Thermodenuder, Aerosol Sci. Tech., 46, 22-30, doi:10.1080/02786826.2011.602762, 2012.

Saleh, R., Donahue, N. M., and Robinson, A. L.: Time Scales for Gas-Particle Partitioning Equilibration of Secondary Organic Aerosol Formed from Alpha-Pinene Ozonolysis, Environ. Sci. Technol., 47, 5588-5594, doi:10.1021/es400078d, 2013.

Schichtel, B. A., Malm, W. C., Bench, G., Fallon, S., McDade, C. E., Chow, J. C., and Watson, J. G.: Fossil and contemporary fine particulate carbon fractions at 12 rural and urban sites in the United States, J. Geophys. Res.-Atmos., 113, D02311, doi:10.1029/2007JD008605, 2008.

Seinfeld, J. H. and Pankow, J. F.: Organic Atmospheric Particulate Material, Annu. Rev. Phys. Chem., 54, 121-140, doi:10.1146/annurev.physchem.54.011002.103756, 2003.

Shrivastava, M., Fast, J., Easter, R., Gustafson Jr., W. I., Zaveri, R. A., Jimenez, J. L., Saide, P., and Hodzic, A.: Modeling organic aerosols in a megacity: comparison of simple and complex representations of the volatility basis set approach, Atmos. Chem. Phys., 11, 6639-6662, doi:10.5194/acp-11-6639-2011, 2011.

Shrivastava, M., Zelenyuk, A., Imre, D., Easter, R., Beranek, J., Zaveri, R. A., and Fast, J.: Implications of low volatility SOA and gas-phase fragmentation reactions on SOA loadings and their spatial and temporal evolution in the atmosphere, J. Geophys. Res.-Atmos., 118, 3328-3342, doi:10.1002/jgrd.50160, 2013.

Sindelarova, K., Granier, C., Bouarar, I., Guenther, A., Tilmes, S., Stavrakou, T., Müller, J.-F., Kuhn, U., Stefani, P., and Knorr, W.: Global data set of biogenic VOC emissions calculated by the MEGAN model over the last 30 years, Atmos. Chem. Phys., 14, 9317-9341, doi:10.5194/acp-14-9317-2014, 2014.

Stanier, C. O., Donahue, N., and Pandis, S. N.: Parameterization of secondary organic aerosol mass fractions from smog chamber data, Atmos. Environ., 42, 2276-2299, doi:10.1016/j.atmosenv.2007.12.042, 2008.
Tarvainen, V., Hakola, H., Hellén, H., Bäck, J., Hari, P., and Kulmala, M.: Temperature and light dependence of the VOC emissions of Scots pine, Atmos. Chem. Phys., 5, 989-998, doi:10.5194/acp-5-989-2005, 2005.

Vaden, T. D., Imre, D., Beránek, J., Shrivastava, M., and Zelenyuk, A.: Evaporation kinetics and phase of laboratory and ambient secondary organic aerosol, P. Natl. Acad. Sci., 108, 2190-2195, doi:10.1073/pnas.1013391108, 2011.

Wang, K., Zhang, Y., Yahya, K., Wu, S.-Y., and Grell, G.: Implementation and initial application of new chemistry-aerosol options in WRF/Chem for simulating secondary organic aerosols and aerosol indirect effects for regional air quality, Atmos. Environ., 115, 716-732, doi:10.1016/j.atmosenv.2014.12.007, 2015.

Warneke, C., de Gouw, J. A., Del Negro, L., Brioude, J., McKeen, S., Stark, H., Kuster, W. C., Goldan, P. D., Trainer, M., Fehsenfeld, F. C., Wiedinmyer, C., Guenther, A. B., Hansel, A., Wisthaler, A., Atlas, E., Holloway, J. S., Ryerson, T. B., Peischl, J., Huey, L. G., and Hanks, A. T. C.: Biogenic emission measurement and inventories determination of biogenic emissions in the eastern United States and Texas and comparison with biogenic emission inventories, J. Geophys. Res.-Atmos., 115, D00F18, doi:10.1029/2009JD012445, 2010.

Weber, R. J., Sullivan, A. P., Peltier, R. E., Russell, A., Yan, B., Zheng, M., de Gouw, J., Warneke, C., Brock, C., Holloway, J. S., Atlas, E. L., and Edgerton, E.: A study of secondary organic aerosol formation in the anthropogenic-influenced southeastern United States, J. Geophys. Res.-Atmos., 112, D13302, doi:10.1029/2007JD008408, 2007.

Wilson, J., Imre, D., Beránek, J., Shrivastava, M., and Zelenyuk, A.: Evaporation Kinetics of Laboratory-Generated Secondary Organic Aerosols at Elevated Relative Humidity, Environ. Sci. Technol., 49, 243-249, doi:10.1021/es505331d, 2015.

Xu, L., Suresh, S., Guo, H., Weber, R. J., and Ng, N. L.: Aerosol characterization over the southeastern United States using highresolution aerosol mass spectrometry: spatial and seasonal variation of aerosol composition and sources with a focus on organic nitrates, Atmos. Chem. Phys., 15, 7307-7336, doi:10.5194/acp15-7307-2015, 2015a.

Xu, L., Guo, H., Boyd, C. M., Klein, M., Bougiatioti, A., Cerully, K. M., Hite, J. R., Isaacman-VanWertz, G., Kreisberg, N. M., Knote, C., Olson, K., Koss, A., Goldstein, A. H., Hering, S. V., de Gouw, J., Baumann, K., Lee, S.-H., Nenes, A., Weber, R. J., and Ng, N. L.: Effects of anthropogenic emissions on aerosol formation from isoprene and monoterpenes in the southeastern United States, P. Natl. Acad. Sci., 112, 37-42, doi:10.1073/pnas.1417609112, 2015 b.

Xu, L., Williams, L. R., Young, D. E., Allan, J. D., Coe, H., Massoli, P., Fortner, E., Chhabra, P., Herndon, S., Brooks, W. A., Jayne, J. T., Worsnop, D. R., Aiken, A. C., Liu, S., Gorkowski, K., Dubey, M. K., Fleming, Z. L., Visser, S., Prévôt, A. S. H., and Ng, N. L.: Wintertime aerosol chemical composition, volatility, and spatial variability in the greater London area, Atmos. Chem. Phys., 16, 1139-1160, doi:10.5194/acp-16-1139-2016, 2016.

Yahya, K., Glotfelty, T., Wang, K., Zhang, Y., and Nenes, A.: Modeling Regional Air Quality and Climate: Improving Organic Aerosol and Aerosol Activation Processes in WRF/Chem version 3.7.1, Geosci. Model Dev. Discuss., doi:10.5194/gmd-2016288, in review, 2016. 
Yarwood, G., Jung, J., Whitten, G., Heo, G., Mellberg, J., and Estes, M.: Updates to the Carbon Bond Mechanism for Version 6 (CB6)." Presented at the 9th Annual CMAS Conference, 1113 October 2010, Chapel Hill, USA, 2010.

Zhang, Q., Jimenez, J. L., Canagaratna, M. R., Allan, J. D., Coe, H., Ulbrich, I., Alfarra, M. R., Takami, A., Middlebrook, A. M., Sun, Y. L., Dzepina, K., Dunlea, E., Docherty, K., DeCarlo, P. F., Salcedo, D., Onasch, T., Jayne, J. T., Miyoshi, T., Shimono, A., Hatakeyama, S., Takegawa, N., Kondo, Y., Schneider, J., Drewnick, F., Borrmann, S., Weimer, S., Demerjian, K., Williams, P., Bower, K., Bahreini, R., Cottrell, L., Griffin, R. J., Rautiainen, J., Sun, J. Y., Zhang, Y. M., and Worsnop, D. R.: Ubiquity and dominance of oxygenated species in organic aerosols in anthropogenically-influenced Northern Hemisphere midlatitudes, Geophys. Res. Lett., 34, L13801, doi:10.1029/2007GL029979, 2007.
Zhang, X., Cappa, C. D., Jathar, S. H., McVay, R. C., Ensberg, J. J., Kleeman, M. J., and Seinfeld, J. H.: Influence of vapor wall loss in laboratory chambers on yields of secondary organic aerosol, P. Natl. Acad. Sci., 111, 5802-5807, doi:10.1073/pnas.1404727111, 2014.

Zhang, X., McVay, R. C., Huang, D. D., Dalleska, N. F., Aumont, B., Flagan, R. C., and Seinfeld, J. H.: Formation and evolution of molecular products in $\alpha$-pinene secondary organic aerosol, P. Natl. Acad. Sci., 112, 14168-14173, doi:10.1073/pnas.1517742112, 2015.

Zobrist, B., Marcolli, C., Pedernera, D. A., and Koop, T.: Do atmospheric aerosols form glasses?, Atmos. Chem. Phys., 8, 52215244, doi:10.5194/acp-8-5221-2008, 2008. 